\title{
Rebelling against the (Insulin) Resistance: A Review of the Proposed Insulin-Sensitizing Actions of Soybeans, Chickpeas, and Their Bioactive Compounds
}

\author{
Jaime L. Clark 1,2 (iD, Carla G. Taylor 1,2,3 (iD) and Peter Zahradka 1,2,3,* \\ 1 Canadian Centre for Agri-Food Research in Health and Medicine, St. Boniface Hospital Albrechtsen \\ Research Centre, Winnipeg, MB R2H 2A6, Canada; jclark@sbrc.ca (J.L.C.); ctaylor@sbrc.ca (C.G.T.) \\ 2 Department of Food and Human Nutritional Sciences, University of Manitoba, \\ Winnipeg, MB R3T 2N2, Canada \\ 3 Department of Physiology and Pathophysiology, University of Manitoba, Winnipeg, MB R3E 0T5, Canada \\ * Correspondence: pzahradka@sbrc.ca; Tel.: +1-204-235-3507
}

Received: 15 February 2018; Accepted: 28 March 2018; Published: 30 March 2018

\begin{abstract}
Insulin resistance is a major risk factor for diseases such as type 2 diabetes and metabolic syndrome. Current methods for management of insulin resistance include pharmacological therapies and lifestyle modifications. Several clinical studies have shown that leguminous plants such as soybeans and pulses (dried beans, dried peas, chickpeas, lentils) are able to reduce insulin resistance and related type 2 diabetes parameters. However, to date, no one has summarized the evidence supporting a mechanism of action for soybeans and pulses that explains their ability to lower insulin resistance. While it is commonly assumed that the biological activities of soybeans and pulses are due to their antioxidant activities, these bioactive compounds may operate independent of their antioxidant properties and, thus, their ability to potentially improve insulin sensitivity via alternative mechanisms needs to be acknowledged. Based on published studies using in vivo and in vitro models representing insulin resistant states, the proposed mechanisms of action for insulin-sensitizing actions of soybeans, chickpeas, and their bioactive compounds include increasing glucose transporter- 4 levels, inhibiting adipogenesis by down-regulating peroxisome proliferator-activated receptor- $\gamma$, reducing adiposity, positively affecting adipokines, and increasing short-chain fatty acid-producing bacteria in the gut. Therefore, this review will discuss the current evidence surrounding the proposed mechanisms of action for soybeans and certain pulses, and their bioactive compounds, to effectively reduce insulin resistance.
\end{abstract}

Keywords: soybeans; pulses; chickpeas; insulin resistance; bioactive compounds; GLUT4; PPAR $\gamma$; adipokines; adiponectin; short-chain fatty acids

\section{Introduction}

It is well known that insulin resistance is a condition that lays the foundation for diseases such as metabolic syndrome, type 2 diabetes, and cardiovascular disease [1]. As the precursor to the onset of overt disease, insulin resistance is characterized by a reduced cellular response to insulin and this requires the body to compensate by increasing insulin secretion to obtain the biological effects normally achieved with a lower amount of insulin [2,3]. While the exact cause of insulin resistance is unknown, there are multiple factors that can contribute to the reduced insulin sensitivity of target cells, including genetic and lifestyle factors [4]. 
Current therapeutic strategies for attenuating insulin resistance aim to encourage lifestyle modifications (e.g., diet, exercise, weight loss) as a first-line offense prior to the administration of pharmacological agents (e.g., insulin-sensitizing drugs) to patients [5]. The goal of pharmacotherapy in this disease context is to restore the normal relationship between insulin sensitivity and secretion [6]. However, due to the contrary complications of insulin-sensitizer drugs, alternative remedies for attenuating insulin resistance in the form of dietary agents are receiving more interest among patients and practitioners [7].

Legumes are an integral part of a healthy diet as they are rich in fibre, protein, complex carbohydrates and micronutrients, and contain no cholesterol $[8,9]$. In addition to their nutritional benefits, most legumes contain a variety of bioactive compounds that may add to their functional health benefits [10]. Legumes such as soybeans and pulses are known to be beneficial for diabetes management due to their low glycemic index [11,12], defined as producing a relatively low rise in blood glucose following their consumption [13]. Soybeans and pulses are both members of the Leguminosae family; however, the soybeans are grouped separately [12]. Both groups are nitrogen-fixing, meaning they produce their own nitrogen compounds that are released into the soil, thus eliminating the need for chemical fertilizers [14]. The primary characteristic that separates soybeans from pulses is that soybeans are oil-producing plants commonly harvested for the purpose of producing soybean oil, while pulses (dried beans, dried peas, chickpeas, lentils) are harvested dry as edible seeds [12]. Both are important sources of plant-based dietary protein world-wide $[15,16]$; in Asian countries, soybeans, in particular, are the major protein source for over one billion people [16]. In addition to their diabetes management properties, many clinical studies support the concept that consuming soybeans and pulses is favorable as a result of the ability to attenuate insulin resistance as shown by improvements in the homeostasis modelling assessment-insulin resistance (HOMA-IR) index and fasting insulin levels (Table 1) [5,17-26], although some studies have reported opposing [24] or null effects [25,27-29]. To this point, however, no one has summarized the evidence supporting the proposed mechanisms of action for soybeans and pulses in the context of insulin resistance. To address this gap in knowledge, this review will discuss the current evidence surrounding the proposed mechanisms of action for soybeans, certain pulses, and their bioactive compounds, to effectively reduce insulin resistance. 
Table 1. Clinical trials investigating the efficacy of soybeans and pulses to improve insulin sensitivity.

\begin{tabular}{|c|c|c|c|c|c|}
\hline Legume & Author & Study Design & $\begin{array}{l}\text { Participants and Disease } \\
\text { State/Condition }\end{array}$ & Intervention & Results \\
\hline \multirow{5}{*}{ Soy (Glycine max. L.) } & Llaneza et al. [5] & $\begin{array}{l}\text { Randomized (R), controlled, } \\
\text { single-blinded (SB) } \\
\text { Longitudinal study } \\
\text { (24 months) }\end{array}$ & $\begin{array}{l}\text { Postmenopausal women } \\
\text { (50-64 years old) } \\
\text { Normal to obese body mass } \\
\text { index }\left(22.5 \text { to } 43.5 \mathrm{~kg} / \mathrm{m}^{2}\right)\end{array}$ & $\begin{array}{l}\text { Control: physical exercise + } \\
\text { Mediterranean diet } \\
\text { Intervention: control + } \\
80 \mathrm{mg} \text { soy isoflavone } \\
\text { extract/day (ISO) }\end{array}$ & $\begin{array}{l}\text { ISO } \downarrow \text { fat mass, fasting serum glucose } \\
\& \text { insulin, and HOMA-IR vs. baseline } \\
\text { ISO } \downarrow \text { fat mass, and HOMA-IR vs. } \\
\text { control at } 24 \text { months } \\
\text { ISO had greater } \downarrow \text { effect on HOMA-IR, } \\
\text { and fasting serum glucose \& insulin in } \\
\text { obese participants }\end{array}$ \\
\hline & Choi et al. [17] & $\begin{array}{l}\text { R, double-blinded (DB), } \\
\text { placebo-controlled (PC) } \\
\text { 12-week study }\end{array}$ & $\begin{array}{l}\text { Men and women (mean age } \\
\text { range } 43-53 \text { years old) } \\
\text { Overweight (body mass index } \\
\text { 25.0-29.9 } \mathrm{kg} / \mathrm{m}^{2} \text { ) } \\
\text { Mild hyperglycemia (fasting } \\
\text { blood glucose } 5.5-6.9 \mathrm{mmol} / \mathrm{L} \text { ) }\end{array}$ & $\begin{array}{l}\text { Placebo: } 2 \mathrm{~g} \text { starch } \\
\text { capsules/day } \\
\text { Positive control: } 300 \mathrm{mg} \\
\text { banaba extract/day (BE) } \\
\text { Intervention: } 2 \text { g soybean } \\
\text { leaf extract/day (SLE) }\end{array}$ & $\begin{array}{l}\text { No effect of interventions on body } \\
\text { weight or body mass index } \\
\text { SLE and BE } \downarrow \text { body fat, blood glucose } \\
\text { and HOMA-IR vs. placebo at } 12 \text { weeks }\end{array}$ \\
\hline & Choquette et al. [18] & $\begin{array}{ll}\text { R, DB, PC } \\
\text { 6-month study }\end{array}$ & $\begin{array}{l}\text { Postmenopausal women } \\
\text { (50-70 years old) } \\
\text { Overweight and obese (body } \\
\text { mass index } 28-40 \mathrm{~kg} / \mathrm{m}^{2} \text { ) }\end{array}$ & $\begin{array}{l}\text { Controls: Placebo capsules; } \\
\text { Exercise (resistance and } \\
\text { aerobic training } 3 \times / \text { week) } \\
\text { + placebo capsules } \\
\text { Interventions: } 70 \mathrm{mg} \text { soy } \\
\text { isoflavones/day (ISO); } \\
\text { Exercise + ISO }\end{array}$ & $\begin{array}{l}\text { ISO, without exercise, improved } \\
\text { fasting plasma insulin and HOMA-IR } \\
\text { vs. baseline }\end{array}$ \\
\hline & Fei et al. [19] & $\begin{array}{l}\mathrm{R}, \text { controlled } \\
\quad \text { 8-week study }\end{array}$ & $\begin{array}{l}\text { Pregnant women (single fetus) } \\
\text { Gestational diabetes } \\
\text { (diagnosed according to } \\
\text { National Diabetes Data } \\
\text { Group standard) }\end{array}$ & $\begin{array}{l}\text { Control: insulin }(3 \times / \text { day }) \\
\text { Intervention: } 10 \mathrm{~g} \text { soybean } \\
\text { oligosaccharides/day in } \\
\text { water }(\text { SOGS })+\text { insulin } \\
(3 \times / \text { day })\end{array}$ & $\begin{array}{l}\text { SOGS + insulin } \downarrow \text { fasting plasma } \\
\text { insulin and HOMA-IR vs. control } \\
\text { group at } 8 \text { weeks } \\
\text { SOGS }+ \text { insulin } \downarrow \text { total insulin dosage } \\
\text { vs. control group }\end{array}$ \\
\hline & Jamilian et al. [20] & $\begin{array}{ll}\text { R, DB, PC } \\
\text { 12-week study }\end{array}$ & $\begin{array}{l}\text { Women }(18-40 \text { years old }) \\
\quad \text { Polycystic Ovary Syndrome }\end{array}$ & $\begin{array}{l}\text { Placebo: } 50 \mathrm{mg} \text { capsules } \\
\text { (composition not disclosed) } \\
\text { Intervention: } 50 \mathrm{mg} \text { soy } \\
\text { isoflavones/day (ISO) }\end{array}$ & $\begin{array}{l}\text { ISO } \downarrow \text { serum insulin and HOMA-IR vs. } \\
\text { placebo at } 12 \text { weeks }\end{array}$ \\
\hline
\end{tabular}


Table 1. Cont

\begin{tabular}{|c|c|c|c|c|c|}
\hline Legume & Author & Study Design & $\begin{array}{l}\text { Participants and Disease } \\
\text { State/Condition }\end{array}$ & Intervention & Results \\
\hline Soy (Glycine max. L.) & Ye et al. [27] & $\begin{array}{ll}\cdot & \mathrm{R}, \mathrm{DB}, \mathrm{PC} \\
\cdot & \text { 24-week study }\end{array}$ & $\begin{array}{l}\text { Pre- and post-menopausal } \\
\text { Chinese women } \\
\text { ( } 30-70 \text { years old) } \\
\text { Impaired glucose regulation } \\
\text { (fasting glucose } \\
5.6-7.0 \mathrm{mmol} / \mathrm{L}, 2-\mathrm{h} \\
\text { postprandial glucose } \\
7.8-11.0 \mathrm{mmol} / \mathrm{L} \text {, or newly } \\
\text { diagnosed diabetes not } \\
\text { requiring medication) }\end{array}$ & $\begin{array}{l}\text { Control: } 10 \mathrm{~g} \text { soy protein } \\
\text { Interventions: control + } \\
50 \mathrm{mg} / \text { day daidzein; } \\
\text { control + } \\
50 \mathrm{mg} / \text { day genistein }\end{array}$ & $\begin{array}{l}\text { No differences in fasting glucose or } \\
\text { insulin levels } \\
\text { No differences in insulin sensitivity }\end{array}$ \\
\hline \multirow{3}{*}{$\begin{array}{l}\text { Beans (Phaseolus } \\
\text { vulgaris L.) }\end{array}$} & Bourdon et al. [28] & $\begin{array}{ll}\text { Cross-over }(\mathrm{CO}) \\
3 \times 6 \text {-h visits }+ \\
3 \times 1-3 \text { week washouts }\end{array}$ & $\begin{array}{l}\text { Men }(21-45 \text { years old }) \\
\text { Healthy (body mass index } \\
\left.22.6-29.4 \mathrm{~kg} / \mathrm{m}^{2}\right)\end{array}$ & $\begin{array}{l}\text { Control: instant rice and } \\
\text { dry milk + test meal } \\
\text { Intervention: } 60 \mathrm{~g} \text { white } \\
\text { bean flakes + test meal }\end{array}$ & $\begin{array}{l}\text { No differences in fasting postprandial } \\
\text { blood glucose or insulin levels } \\
\text { between meals }\end{array}$ \\
\hline & Nilsson et al. [21] & $\begin{array}{ll}\mathrm{R}, \mathrm{CO} \\
\quad 2 \times 3 \text {-h visits }\end{array}$ & $\begin{array}{l}\text { Men and women (mean age } \\
24 \pm 1 \text { years old) } \\
\text { Healthy (body mass index } \\
22.5 \pm 0.6 \mathrm{~kg} / \mathrm{m}^{2} \text { ) }\end{array}$ & $\begin{array}{l}\text { Evening meals: } \\
\text { Control: } 89 \mathrm{~g} \text { white wheat } \\
\text { bread (WB) } \\
\text { Intervention: } 101 \mathrm{~g} \text { cooked } \\
\text { Swedish brown beans } \\
\text { Next-day: } \\
\text { standardized breakfast }\end{array}$ & $\begin{array}{l}\text { Brown beans } \downarrow \text { postprandial glucose } \\
\text { and insulin incremental area under the } \\
\text { curve }(0-120 \text { min) vs. WB } \\
\text { No differences in fasting glucose and } \\
\text { insulin concentrations between } \\
\text { evening meals }\end{array}$ \\
\hline & Reverri et al. [22] & $\begin{array}{l}\mathrm{R} \text {, controlled, } \\
\text { cross-over }(\mathrm{CO}) \\
3 \times 5 \text {-h visits }+ \\
3 \times 1 \text {-week washouts }\end{array}$ & $\begin{array}{l}\text { Men and women (mean age } \\
49 \pm 14 \text { years old) } \\
\text { Metabolic syndrome (body } \\
\text { mass index } 32.2 \pm 5.7 \mathrm{~kg} / \mathrm{m}^{2} ; \\
\text { insulin resistant) }\end{array}$ & $\begin{array}{l}\text { Controls: fibre-matched } \\
\text { meal (FM) and } \\
\text { antioxidant-matched meal } \\
\text { (AM; } 300 \text { mg grape seed } \\
\text { extract supplemented) } \\
\text { Intervention: black bean } \\
\text { meal (BB) }\end{array}$ & $\begin{array}{l}\text { No difference in postprandial blood } \\
\text { glucose levels between meals } \\
\text { BB } \downarrow \text { plasma insulin vs. controls }\end{array}$ \\
\hline $\begin{array}{l}\text { Beans (Phaseolus } \\
\text { vulgaris L.) and Peas } \\
\text { (Pisum sativum L.) }\end{array}$ & Winham et al. [29] & $\begin{array}{l}\mathrm{R}, \mathrm{CO}, 33 \times \text { block design } \\
3 \times 8 \text {-week arms }+ \\
2 \times 2 \text {-week washouts }\end{array}$ & $\begin{array}{l}\text { Men and women } \\
\text { (22-65 years old) } \\
\text { Moderately insulin resistant } \\
\text { (fasting insulin } \geq 15 \mu \mathrm{U} / \mathrm{mL} \\
\text { and } \leq 50 \mu \mathrm{U} / \mathrm{mL} \text { ) }\end{array}$ & $\begin{array}{l}\text { Control: } 1 / 2 \text { cup canned } \\
\text { sliced carrots/day } \\
\text { Interventions: } 1 / 2 \text { cup } \\
\text { canned pinto beans; } 1 / 2 \text { cup } \\
\text { canned black-eyed peas }\end{array}$ & $\begin{array}{l}\text { No difference in fasting blood glucose } \\
\text { and insulin levels } \\
\text { No difference in HOMA-IR }\end{array}$ \\
\hline
\end{tabular}


Table 1. Cont.

\begin{tabular}{|c|c|c|c|c|c|}
\hline Legume & Author & Study Design & $\begin{array}{c}\text { Participants and Disease } \\
\text { State/Condition }\end{array}$ & Intervention & Results \\
\hline $\begin{array}{l}\text { Peas (Pisum } \\
\text { sativum L.) }\end{array}$ & $\begin{array}{c}\text { Marinangeli \& Jones } \\
\text { [23] }\end{array}$ & $\begin{array}{l}\mathrm{R}, \mathrm{SB}, \mathrm{CO} \\
3 \times 4 \text {-week arms }+ \\
3 \times 4 \text {-week washouts }\end{array}$ & $\begin{array}{l}\text { Men and women (mean ages } \\
51.8 \pm 12.3 \text { and } \\
52.3 \pm 10.0 \text { years old, respectively) } \\
\text { Overweight (body mass index } \\
25-40 \mathrm{~kg} / \mathrm{m}^{2} \text { ) } \\
\text { Hypercholesterolemic }\end{array}$ & $\begin{array}{l}\text { Control: white wheat } \\
\text { flour muffins } \\
\text { Intervention: whole pea } \\
\text { flour (WPF) or fractioned } \\
\text { pea flour (FPF) muffins; } \\
50 \text { g dried yellow peas / day }\end{array}$ & $\begin{array}{l}\text { No change in body weight } \\
\text { No differences in postprandial blood } \\
\text { glucose levels } \\
\text { WPF and FPF } \downarrow \text { fasting plasma insulin } \\
\text { and HOMA-IR vs. control }\end{array}$ \\
\hline \multirow{3}{*}{$\begin{array}{l}\text { Chickpeas (Cicer } \\
\text { arietinum L.) }\end{array}$} & Johnson et al. [24] & $\begin{array}{l}\mathrm{R}, \mathrm{SB}, \mathrm{CO} \\
3 \times 175 \text {-min visits }+ \\
3 \times 7 \text {-day } \\
\text { (minimum) washouts }\end{array}$ & $\begin{array}{l}\text { Men and women (mean age } \\
32 \pm 2 \text { years old) } \\
\text { Healthy (body mass index } \\
24.7 \pm 0.8 \mathrm{~kg} / \mathrm{m}^{2} \text { ) }\end{array}$ & $\begin{array}{l}\text { Control: } 3-4 \text { toasted slices } \\
\text { of white bread (WB) } \\
\text { Interventions: } 3-4 \text { toasted } \\
\text { slices of chickpea bread } \\
\text { (CB) or extruded chickpea } \\
\text { bread (EXB) }\end{array}$ & $\begin{array}{l}\mathrm{CB} \text { and } \mathrm{EXB} \downarrow \text { incremental plasma } \\
\text { glucose concentrations at } 90 \text { min and } \\
120 \text { min, respectively, vs. WB } \\
\mathrm{CB} \uparrow \text { serum insulin incremental area } \\
\text { under the curve vs. WB }\end{array}$ \\
\hline & Nestel et al. [25] & $\begin{array}{l}\text { Acute study: } 3 \times 3 \text {-h visits } \\
\text { Long-term study: } \mathrm{R}, \mathrm{CO} \\
2 \times 6 \text {-week arms }\end{array}$ & $\begin{array}{l}\text { Men and women (acute study } \\
\text { mean age } 62 \pm 6 \text { years old; } \\
\text { long-term study mean age } \\
57 \pm 8 \text { years old) } \\
\text { Healthy (acute study body } \\
\text { mass index } 26.5 \pm 3.8 \mathrm{~kg} / \mathrm{m}^{2} \\
\text { long-term study body mass } \\
\text { index } 25.6 \pm 3.2 \mathrm{~kg} / \mathrm{m}^{2} \text { ) }\end{array}$ & $\begin{array}{l}\text { Acute study } \\
\text { Control: white bread } \\
\text { Interventions: cooked, } \\
\text { mashed chickpeas (200 g) or } \\
\text { wheat cereal with } \\
\text { wheat bran } \\
\text { Long-term study } \\
\text { Interventions: } \\
\text { chickpea-foods (from } 140 \mathrm{~g} \\
\text { canned chickpeas) or } \\
\text { wheat-based foods }\end{array}$ & $\begin{array}{l}\text { Acute study: Chickpea treatment } \downarrow \\
\text { postprandial plasma glucose levels vs. } \\
\text { wheat and control treatments at } 30 \text { and } \\
60 \text { min; chickpea treatment } \downarrow \text { fasting } \\
\text { plasma insulin levels and HOMA-IR } \\
\text { vs. wheat and control treatments } \\
\text { Long-term study: No differences in } \\
\text { fasting plasma glucose or insulin levels } \\
\text { or HOMA-IR }\end{array}$ \\
\hline & Pittaway et al. [26] & $\begin{array}{l}\text { CO } \\
\text { 20-week study (4 weeks } \\
\text { regular diet }+12 \text { weeks } \\
\text { intervention }+4 \text { weeks } \\
\text { regular diet) }\end{array}$ & $\begin{array}{l}\text { Men and women } \\
\text { ( } 30-70 \text { years old) } \\
\text { Overweight }(\text { mean body mass } \\
\text { index } 26.3 \pm 4.8 \mathrm{~kg} / \mathrm{m}^{2} \text { ) } \\
\text { Mildly hypercholesterolemic } \\
\text { (mean fasting serum total } \\
\text { cholesterol } 6.5 \pm 1.4 \mathrm{mmol} / \mathrm{L} \text { ) } \\
\text { Normoglycemic }\end{array}$ & $\begin{array}{l}\text { Control: regular diet } \\
\text { Intervention: average } 119 \mathrm{~g} \\
\text { canned chickpeas/day } \\
\text { (Chickpea diet) }\end{array}$ & $\begin{array}{l}\text { Chickpea diet } \downarrow \text { fasting serum insulin } \\
\text { and HOMA-IR vs. regular diet after } \\
12 \text { week intervention }\end{array}$ \\
\hline
\end{tabular}

Abbreviations: $\downarrow$, decrease; $\uparrow$, increase; AM, antioxidant-matched; BB, black bean meal; BE, banaba extract; CB, chickpea bread; CO, cross-over; DB, double-blind; EXB, extruded chickpea bread; FM, fibre-matched; FPF, fractioned pea flour; HOMA-IR, homeostasis modelling assessment-insulin resistance; ISO, soy isoflavones; PC, placebo-controlled; R, randomized; SB, single-blind; SLE, soy leaf extract; SOGS, soybean oligosaccharides WB, white bread; WPF, whole pea flour. 


\section{The Search Strategy Used for This Review}

The intent of this review was to summarize the information pertaining to soybeans and the four major pulses grown in North America (dried beans, dried peas, chickpeas, lentils) with respect to their proposed insulin-sensitizing actions. However, based on the literature search, most of the studies were on soybeans and chickpeas, with limited information available for dried beans, dried peas, and lentils. The literature search was conducted using the PubMed database through the University of Manitoba library with combinations of the following key terms: "soybeans", "pulses", "chickpeas", "lentils", "beans", "peas", "legumes", "phaseolus vulgaris", "insulin resistance", "insulin sensitivity", and "insulin sensitizing". There were 8 clinical studies examining the insulin-sensitizing effects of soybeans and certain pulses (dried beans, dried peas, chickpeas), but none for lentils.

With respect to studies investigating potential mechanisms, 11 preclinical studies were identified and these studies examined only soybeans or chickpea. Upon critical evaluation of these studies, additional key terms pertinent to the identified bioactive compounds were added to the word combinations used in the literature search, such as: "isoflavones", "anthocyanins", "alpha-galactooligosaccharides", and "oligosaccharides". This secondary search yielded four additional studies that were included in this review. The 15 preclinical studies obtained were used to identify the proposed mechanism(s) of action with respect to improving insulin sensitivity, and these studies focused largely on adipose tissue and related molecules.

It is important to note that there was limited information regarding the genus, species, and variety of the legume plants investigated in these studies, thus making it difficult in some cases to determine exactly which plant was being investigated. We believe this information is necessary to properly identify the plant(s) being examined, and therefore we recommend that future publications include such information.

\section{The Bioactive Compounds of Soybeans and Pulses Discussed in This Review}

\subsection{Isoflavones}

Isoflavones are bioactive compounds that belong to a class of secondary metabolites known as flavonoids, a diverse range of polyphenolic compounds found in plants [30]. Isoflavones are present in more than 300 different types of plants [31], with legumes, such as soybeans and chickpeas, being major sources [31-33].

Soybeans are the best-known source of isoflavones, including the major isoflavone aglycones, genistein, daidzein and glycitein, and their respective glycoside conjugates, genistin, daidzin, and glycitin [31,34]. Chickpeas also contain genistein and daidzein; however, the major isoflavones found in chickpeas are biochanin A (aglycone and glucoside forms) and formonentin [32]. The relevant isoflavone compounds in soybeans and chickpeas with regard to this review are summarized in Figure 1.

Isoflavones are most notable for their phytoestrogen activity, which is due to their weak affinity for estrogen receptors $[33,35]$. Thus, isoflavones have been commonly characterized in relation to cancers, cardiovascular disease, inflammation, and diabetes [33,35]. Their proposed anti-diabetic activity is reportedly due to their ability to attenuate insulin resistance and improve insulin secretion [32], with evidence to support these claims found in various clinical trials [5,17-19]. 


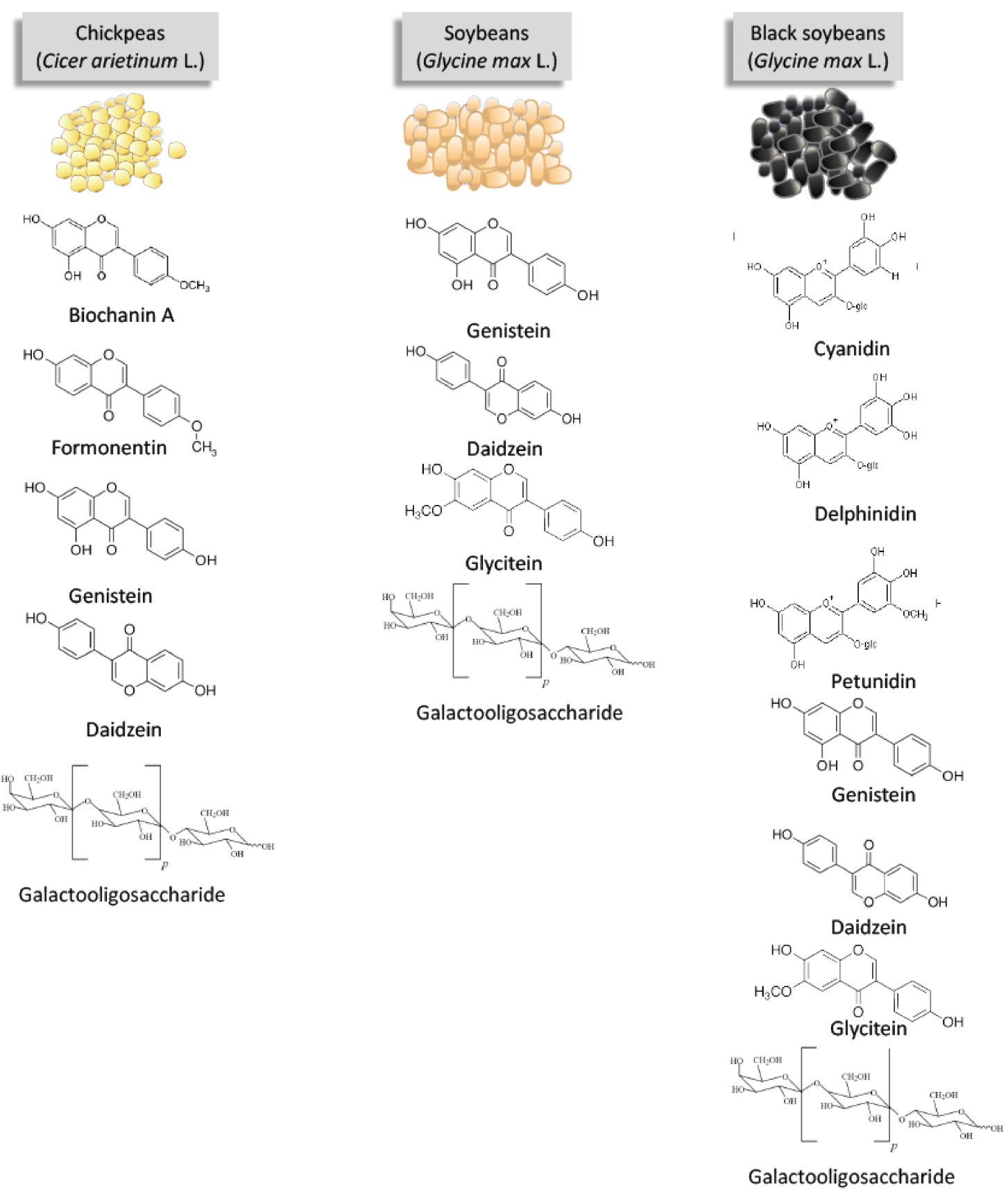

Figure 1. The bioactive compounds present in soybeans and chickpeas as discussed in this review.

\subsection{Anthocyanins}

Anthocyanins are the most vibrant class of flavonoids, being responsible for the red, blue, and purple pigments of plants [30]. The most common sources of anthocyanins are blue-, red-, and purple-hued fruits (e.g., blueberries, blackberries, strawberries) [30,36], but they are also found in legumes, such as beans with darker-coloured seed coats (e.g., black soybeans, black beans and red kidney beans) $[37,38]$.

The most common anthocyanins found in plants are cyanidin, delphinidin, pelargonidin, peonidin, petunidin, and malvidin [36]. The types of anthocyanins present in black soybeans remain to be elucidated; however, studies have consistently confirmed the presence of at least three anthocyanins: cyanidin-3-glucoside, delphinidin-3-glucoside, and petunidin-3-glucoside (Figure 1) [39,40]. 
Similar to isoflavones, anthocyanins are associated with health-promoting properties with respect to cardiovascular disease, cancer, inflammation, and diabetes, and typically ascribed to their antioxidant activity [39]. Dietary anthocyanins have also been associated with improvements in insulin sensitivity [39], making them a potential dietary ammunition against insulin resistance.

\subsection{Galactooligosaccharides}

Galactooligosaccharide (GOS) is a term that collectively describes a heterogeneous group of carbohydrates composed of 1 to 10 galactosyl moieties [41,42]. GOS are naturally found in human and bovine milk sources [42,43], but can also be found in foods such as chickpeas and soybeans [19,40], and are commercially manufactured from lactose using $\beta$-galactosidase [42]. The general structure of galactooligosaccharides can be viewed in Figure 1.

GOS function as one of the most potent prebiotics and have several health benefits including promotion of gastrointestinal health and weight management, and prevention of carcinogenesis, to name a few [44]. The ability of GOS to improve insulin sensitivity has been proposed and will be discussed within the scope of this review.

\section{The Proposed Mechanisms of Action for Reduction of Insulin Resistance by Soybeans and Pulses}

\subsection{Glucose Transporter-4 and Glucose Utilization}

Under normal conditions, pancreatic $\beta$-cells release insulin in amounts that correspond to changes in plasma glucose concentrations [45]. Glucose is then removed from the circulation by uptake into the cells of insulin-sensitive tissues (skeletal muscle, adipose) via glucose transporter-4 (GLUT4) for energy utilization or storage [46]. The presence of circulating insulin stimulates around $50 \%$ of intracellular GLUT4 to be redistributed from storage vesicles in the cytosol to the plasma membrane [46,47]. Studies have shown that in patients with type 2 diabetes, where insulin resistance is present, the expression and translocation of GLUT4 is significantly reduced [32,46]. Therefore, increasing the levels and translocation of GLUT4 is a crucial factor in regulating glucose tolerance and insulin sensitivity to prevent the development of insulin resistance [46-48].

Bioactive compounds from soybeans and pulses have been investigated for their efficacy in improving glucose utilization and insulin sensitivity via increasing GLUT4 gene expression and/or plasma membrane levels. Huang et al. [49] used black soybean koji (a fermented black soybean product) to prepare an extract for treating 3T3-L1 preadipocytes. Preadipocytes are commonly used in insulin resistance studies to determine effects on adipogenesis and related processes, such as glucose uptake $[50,51]$. Insulin resistance was induced in the preadipocytes by treating with dexamethasone and insulin for $60 \mathrm{~h}$ (eight days is required to obtain mature adipocytes under the culture conditions), a method shown to promote insulin resistance in this cell line [52]. The black soybean koji extract increased protein levels of GLUT4 in a dose-dependent manner from 25 to $200 \mu \mathrm{g} / \mathrm{mL}$ compared with the vehicle treatment in the preadipocytes [49]. Furthermore, the highest concentration of black soybean koji extract $(200 \mu \mathrm{g} / \mathrm{mL})$ significantly increased glucose utilization in the preadipoctyes compared with the vehicle treatment. Huang et al. [49] analyzed the black soybean extract for isoflavone content but not for other flavonoids, such as anythocyanins, which are responsible for the black seed coat colour of this soybean variety and have been shown in other studies to increase GLUT4 expression [38]. A study conducted by Inaguma et al. [53] is in accordance with the supposition that it is the anthocyanins in black soybeans that are responsible for increased glucose uptake. They treated adipocytes (3T3-L1 cells) with the anthocyanin, cyanidin 3-glucoside (20 and $100 \mu \mathrm{M})$, after extraction from black soybeans [53]. Both cyanidin 3-glucoside concentrations significantly increased mRNA levels of GLUT4 compared to the vehicle treatment.

Improved glucose utilization due to black soybean anthocyanins was also demonstrated in a diabetic model in vivo [38]. Diabetes was induced in male Sprague Dawley rats by injecting 
streptozotocin $(50 \mathrm{mg} / \mathrm{kg})$. In the diabetic control groups, blood glucose levels increased, blood insulin concentrations decreased, and cardiac and skeletal muscle GLUT4 protein levels declined [38]. Administration by oral gavage of anthocyanins $(50 \mathrm{mg} / \mathrm{kg}$ ) extracted from black soybeans to the diabetic rats for 30 days reduced blood glucose levels, increased circulating insulin concentrations, and increased GLUT4 translocation and insulin receptor phosphorylation in heart and skeletal muscle, compared to the diabetic control group [38].

A study using anthocyanins extracted from a non-legume source supports anthocyanins being the class of compounds responsible for improving GLUT4 levels [54]. An anthocyanin-rich purple corn water extract significantly increased glucose uptake in insulin resistant adipocytes compared to vehicle treatment [48]. Cyanidin 3-glucoside, the major anthocyanin present in the purple corn extract, administered on its own also increased glucose uptake in insulin resistance adipocytes [54].

In contrast, Gao et al. [32] reported that treatment of 3T3-L1 adipocyte cells with isoflavones extracted from chickpeas (concentrations of $50 \mu \mathrm{g} / \mathrm{mL}$ and $100 \mu \mathrm{g} / \mathrm{mL}$ ) significantly reduced GLUT4 mRNA and protein levels in a dose-dependent manner compared to vehicle treated adipocytes. While it was observed that chickpea isoflavones decrease GLUT4 levels [32], the adipocytes were not made insulin resistant as was the case for the anthocyanin studies described above $[38,49,53,54]$.

Overall, it is apparent from the above studies $[32,38,49,53,54]$ that anthocyanins are the compound responsible for increasing the translocation and expression of GLUT4 in adipocytes under conditions of insulin resistance.

\subsection{Peroxisome Proliferator-Activated Receptor- $\gamma$}

Peroxisome proliferator-activated receptor (PPAR) is a member of the nuclear receptor family of ligand-activated transcription factors [55]. Of the three different isoforms of PPARs, PPAR- $\alpha$ and PPAR- $\gamma$ are commonly studied for their relationships with insulin sensitivity $[55,56]$. PPAR- $\gamma$ is predominantly found in adipose tissue and is an essential regulator of adipocyte differentiation and, thus, is an indirect regulator of glucose and lipid homeostasis [57,58]. Upon activation, PPAR- $\gamma$ facilitates normal insulin sensitivity by directly modulating the activation of specific insulin signaling molecules $[32,57,58]$.

It has been suggested that isoflavones can bind to and activate PPAR- $\gamma$ [59]. In the study conducted by Huang et al. [49], the black soybean koji extract $(200 \mu \mathrm{g} / \mathrm{mL})$, rich in isoflavones, significantly decreased PPAR- $\gamma$ protein levels in insulin resistant 3T3-L1 preadipocytes, compared with vehicle treatment. Similarly, Gao et al. [32] saw that with chickpea isoflavones (50 and $100 \mu \mathrm{g} / \mathrm{mL}$ ) PPAR- $\gamma$ mRNA and protein levels were decreased in 3T3-L1 preadipocytes, compared to control. Gao et al. [32] also showed mRNA and protein levels of CCAT-enhancer-binding protein- $\alpha$ (C/EBP- $\alpha$; a transcription factor that controls PPAR $\gamma$ expression) were reduced by chickpea isoflavones. Separately, anthocyanins extracted from black soybeans $(50 \mu \mathrm{g} / \mathrm{mL})$ also decreased PPAR- $\gamma$ protein levels in differentiated 3T3-L1 adipocytes [60]. The anthocyanin extract from these black soybeans included cyanidin-3-glucoside (68.3\%), delphinidin-3-glucoside $(25.2 \%)$, and petunidin-3-glucoside (6.5\%) [60].

The studies by Gao et al. [32] and Huang et al. [49] indicated that insulin sensitivity was improved in each instance, which presents a couple of questions: (1) is adipocyte maturity a factor in insulin sensitivity; (2) would anthocyanins also inhibit adipocyte differentiation by down-regulating PPAR- $\gamma$ in preadipocytes, or would isoflavones continue to down-regulate PPAR- $\gamma$ in mature adipocytes?

Thiazolidinediones (TZDs) are insulin-sensitizing drugs that bind and activate PPAR- $\gamma$ and stimulate adipocyte differentiation, resulting in increased accumulation of fat deposits $[61,62]$. Interestingly, Kadowaki et al. [59] proposed that TZDs act by increasing the number of small adipocytes via PPAR- $\gamma$, while also decreasing the number of large adipocytes. Both actions will contribute towards alleviating insulin resistance [61]. In this context, it could be speculated that the down-regulation of PPAR- $\gamma$ by isoflavones from chickpeas and soybeans in preadipocytes may prevent the development of large, dysfunctional adipocytes commonly associated with obesity and insulin resistance [63]. 
Therefore, by inhibiting lipid accumulation, isoflavones are improving glucose utilization and insulin sensitivity [49].

It is important to note that neither study mentioned whether PPAR- $\gamma$ was activated or if other insulin signaling genes were activated, and knowing these points would help elucidate the mechanism of action for how isoflavones improve insulin sensitivity via PPAR- $\gamma$.

\subsection{Fat Deposition \& Metabolism}

With chronic excess energy consumption, such as that associated with obesity, triglycerides and other lipid metabolites spill over into non-adipose tissues such as the liver and muscle [55]. This ectopic lipid deposition significantly interferes with intracellular insulin signaling in these tissues, leading to insulin resistance [55].

Pre-clinical studies have demonstrated the ability of legumes and bioactive isoflavone compounds to reduce fat deposition [32,64-66]. Yang et al. [66] investigated the effect of a high-fat diet supplemented with raw, crushed chickpea seeds in 8-week old male Sprague Dawley rats. After 8 months of dietary supplementation, rats fed chickpeas had significantly reduced body weight, epididymal fat pad weights (an indicator of visceral adiposity), and decreased levels of triglycerides in the liver and muscle compared to non-supplemented rats fed a high-fat diet [66]. Additionally, postprandial plasma glucose and insulin levels in chickpea-supplemented rats were lower compared to non-supplemented rats [66]. These results demonstrate that chickpeas can blunt the hyperglycaemic and hyperinsulinaemic effects of a long-term high-fat diet, as well as reduce visceral adiposity and ectopic lipid accumulation [66]. An interesting observation from this study conducted by Yang et al. [66] relates to its use of raw chickpea seeds. While some countries do consume raw chickpea seeds, it is typically advised to cook chickpeas and other pulses to inactivate anti-nutritional factors that can cause undesirable gastrointestinal effects if consumed $[67,68]$. It is unclear in this study whether the observed effects are due to the chickpeas or the anti-nutritional compounds. Separately, Gao et al. [32] showed that treatment of 3T3-L1 adipocytes with isoflavones extracted from chickpeas (extract concentrations of $50 \mu \mathrm{g} / \mathrm{mL}$ and $100 \mu \mathrm{g} / \mathrm{mL}$ ), intracellular lipid accumulation was reduced in a dose-dependent manner compared to control adipocytes.

Soy isoflavones have also been investigated for their in vivo effects on fat deposition and subsequent insulin resistance. In high-fat diet-induced insulin resistant male Sprague Dawley rats, administration of soybean isoflavones $(150 \mathrm{mg} / \mathrm{kg}$ and $450 \mathrm{mg} / \mathrm{kg}$ ) by oral gavage for 30 days significantly reduced total white adipose tissue weight, including epididymal and peri-renal fat pad weights, compared to the insulin resistant control group, with no difference in body weights among the groups [1]. Additionally, fasting insulin levels and HOMA-IR were significantly lower in the rats receiving soybean isoflavones compared to their insulin resistant control counterparts [1]. The effect of soy isoflavones was also investigated in obese and lean spontaneously hypertensive/NIH-corpulent (SHR/N-cp) rats [64]. Dietary soy isoflavone supplementation in both the lean and obese SHR/N-cp rats significantly reduced fat deposition in several fat depots compared to control rats [64]. The soy isoflavone mixture consisted of genistein, daidzein, and glycitein, and was administered at $0.1 \% w / w$ (100 mg isoflavones per kg of diet) in AIN-93G semi-purified diet [64]. This amount equates to around $2.5 \mathrm{mg}$ isoflavones/day based on an approximate average intake of $25 \mathrm{~g}$ diet/day [69]. While there were no data to confirm the presence of insulin resistance in the obese rats, these data in obese SHR/N-cp rats are of interest as this is an insulin-resistant phenotype and the results imply soy isoflavones are efficacious in reducing adiposity in an insulin-resistant state [64].

As previously mentioned, genistein is one of the main isoflavone glucoside conjugates found in soybeans and, to a lesser extent, in chickpeas $[1,32,64]$. Using genistein $(90 \%$ pure) as a dietary supplement $(0.1 \% w / w$ in high-fat diet) for 4 weeks, Choi et al. [65] found that female ovariectomized Sprague Dawley rats had significantly smaller adipocytes, but not fat pad mass, compared to their ovariectomized control counterparts. Smaller adipocytes are more insulin sensitive, thus, it is not surprising that HOMA-IR index was significantly decreased in ovariectomized rats supplemented 
with genistein, reaching a level comparable with the non-ovariectomized sham group fed the high-fat diet [65]. As well, the addition of genistein to the high-fat diet resulted in positive changes to levels of enzymes related to fat synthesis and oxidation, such as reduced hepatic fatty acid synthase activity and increased carnitine palmitoyltransferase, $\beta$-oxidation, and succinate dehydrogenase activity in adipose. Genistein supplementation also resulted in down-regulation of genes responsible for fatty acid synthesis, and up-regulation of genes responsible for fat utilization [65]. While this study was not conducted with genistein extracted from soybeans or chickpeas, it does help elucidate the potential mechanism by which genistein affects fat metabolism, with subsequent improvements in insulin resistance.

Not all studies have reported a positive effect of soy and soy-derived isoflavones on fat deposition. Zanella et al. [70] showed that male C57BL/ $6 \mathrm{~J}$ mice fed a low-fat diet containing soybeans $(8.5 \% w / w)$ for 21 weeks had significantly increased total fat mass and fat pad weights, but not lean mass or total body weight, compared to mice fed the soy-free diet. A similar result was seen when additional genistein was supplemented $(5 \mathrm{mg} / \mathrm{kg} /$ day) by oral gavage. Neither the soy nor genistein treatments influenced glucose metabolism or insulin sensitivity, as determined by postprandial glucose and insulin tolerance testing, respectively [70].

The collective findings from the above soy studies $[58,59,64]$ present the possibility that with respect to adiposity there is no benefit to providing soy in a non-diseased animal model consuming a low-fat diet [70]. However, the evidence supports the conclusion that under conditions of a high-fat diet, supplementing with soy, chickpeas, and/or their respective isoflavones can attenuate insulin resistance, possibly by reducing adiposity [32,64-66].

\subsection{Adipokines}

The relationship between adipose tissue and insulin resistance is well-known: the verdict being that with increased adipose mass, and thus weight gain, there is an impairment of insulin action, leading to insulin resistance [71]. However, increased mass is just one piece of the puzzle in understanding the role adipose plays with insulin resistance. Adipose tissue is an active endocrine organ, producing and secreting proteins known as adipokines [72,73]. Adipocytes become hypertrophic and dysfunctional as adiposity increases, leading to dysregulation of adipokines $[74,75]$. Therefore, in the presence of increased adiposity and insulin resistance, certain adipokines are affected, including adiponectin, leptin, and resistin [72,75]. Given the connection between diet, adiposity, and insulin resistance, it is not surprising that dietary components can influence adipokine levels [76], and thus, have a role in insulin resistance.

\subsubsection{Adiponectin}

Adiponectin is recognized for its many beneficial biological effects, including anti-inflammatory, anti-atherogenic, and anti-diabetic actions [77]. Levels of adiponectin, as measured in the circulation and in adipose tissue, are inversely related to insulin resistance [49,59]. Thus, restoring adiponectin levels is beneficial for attenuating insulin resistance and improving insulin sensitivity [78].

In high-fat diet-induced insulin resistant Sprague Dawley rats, the administration of soybean isoflavones $(150 \mathrm{mg} / \mathrm{kg} /$ day and $450 \mathrm{mg} / \mathrm{kg} /$ day) by oral gavage for 30 days increased both circulating protein and mRNA levels of adiponectin in peri-renal white adipose tissue compared to the insulin resistant rats administered vehicle [1]. Additionally, the soy isoflavones reduced HOMA-IR compared to the insulin resistant control group and there was a significant negative correlation between circulating adiponectin levels and HOMA-IR [1].

The effect of soybean extract was also determined in insulin resistant 3T3-L1 adipocytes in vitro [49,53]. Treatment for $60 \mathrm{~h}$ with isoflavone-rich black soybean koji extract (50 to $200 \mu \mathrm{g} / \mathrm{mL}$ ) significantly increased adiponectin protein levels compared to the vehicle treatment in the study conducted by Huang et al. [49]. In the study by Inaguma et al. [53], the authors referenced a separate study by Han et al. [79] where cyanidin 3-glucoside, the anthocyanin extracted from black 
soybeans, significantly increased adiponectin mRNA levels in 3T3-L1 cells in a dose-dependent manner; unfortunately, we were unable to obtain a copy of this article and therefore cannot comment further on the details of the study.

Based on the above studies, it is not possible to determine which compound(s) present in soy (i.e., anthocyanins or isoflavones), is responsible for the observed increases in adiponectin levels. However, not all studies reported a positive effect of soy isoflavones on adiponectin levels. Using genistein $(90 \%$ pure) as a dietary supplement $(0.1 \% w / w$ in high-fat diet) provided to ovariectomized Sprague Dawley rats for 4 weeks, Choi et al. [65] found no significant differences in the levels of serum adiponectin between control and genistein-supplemented groups. There was, however, an improvement in the insulin resistance index in ovariectomized rats supplemented with genistein [65]. Kavanagh et al. [80] also noted a similar result with regards to adiponectin in mature, premenopausal, insulin-resistant female monkeys supplemented with dietary soy isoflavones (155 mg/day) for 4 months. The dietary supplementation had no effect on plasma adiponectin levels; it did, however, increase insulin area under the curve compared to control group, while there were no differences in glucose area under the curve [80]. The findings from Kavanagh et al. [80] suggest that soybean isoflavones in this instance promote insulin hypersecretion in premenopausal female monkeys.

Tissue levels of adiponectin were not examined in the studies conducted by Choi et al. [65] and Kavanagh et al. [80]. Studies have reported that adiponectin circulates until it binds to specific cell-surface receptors [77]. These adiponectin receptors have been identified in insulin-responsive tissues such as liver, adipose, and skeletal muscle [77]. Therefore, the improvement in the insulin resistance index reported by Choi et al. [65] might be explained by increased adiponectin responsiveness in these tissues.

\subsubsection{Leptin}

Leptin is commonly known for its effects on energy balance and the subsequent relationship with weight gain and adiposity [75,81]. Evidence surrounding the relationship between leptin and insulin resistance is controversial, but it is thought that plasma leptin concentrations are positively correlated with insulin resistance $[59,82]$.

Zhang et al. [1], as previously discussed with adiponectin, measured leptin levels in high-fat diet-induced insulin resistant rats. It was shown that a high dose of soy isoflavones ( $450 \mathrm{mg} / \mathrm{kg} / \mathrm{day}$ ) for 30 days increased circulating protein and adipose mRNA levels of leptin, in spite of reduced adipose weight, compared to the insulin resistant control group [1]. While HOMA-IR levels were reduced with medium and high doses of soy isoflavones (150 and $450 \mathrm{mg} / \mathrm{kg} /$ day, respectively), the authors reported that the negative correlation observed between circulating leptin and HOMA-IR failed to reach statistical significance $(p=0.053)$ [1]. Serum leptin levels were also measured following the dietary supplementation of genistein in ovariectomized rats fed a high-fat diet [65]. Choi et al. [65] noted there were no differences in serum leptin levels between groups after 4 weeks of supplementation. In a separate study conducted by Yang et al. [66], 8-week old male Sprague Dawley rats fed a high-fat diet supplemented with raw, crushed chickpea seeds $(10 \% w / w)$ for 8 months had lower leptin mRNA levels in adipose compared to the untreated high-fat diet group. Chickpea supplementation also resulted in lower HOMA-IR levels, indicating improved insulin sensitivity [66].

The above studies show a discrepancy regarding the potential relationship between leptin and insulin resistance, and the effects of chickpea and soybean isoflavones on leptin levels $[1,65,66]$. Zhang et al. [1] indicated that there is a trend, though not statistically significant $(p=0.053)$, between increased leptin levels and improved insulin sensitivity, which is similar to observations by other authors showing leptin improves insulin sensitivity [75,82]. While Zhang et al. [1] saw changes in leptin levels with soybean isoflavones, Choi et al. [65] reported genistein improved insulin sensitivity but had no effect on leptin levels. Yang et al. [66] showed reduced leptin and HOMA-IR levels from chickpea isoflavones but no correlation analyses were conducted; thus, evidence is inconclusive regarding the impact of leptin on insulin resistance. Without a confirmed relationship between leptin 
and insulin resistance, there is not enough evidence to determine if one particular isoflavone source is more beneficial than the other.

\subsubsection{Resistin}

Resistin is a lesser known adipokine that has been observed to promote insulin resistance [75]. Unfortunately, there are limited studies surrounding the effects of soybeans and pulses on resistin levels. In the study conducted by Zhang et al. [1], both concentrations of soy isoflavones $(150 \mathrm{mg} / \mathrm{kg} / \mathrm{day}$ and $450 \mathrm{mg} / \mathrm{kg} /$ day) significantly lowered plasma resistin levels after 30 days of treatment. Meanwhile, only the higher dose (450 mg/kg/day) of soy isoflavones lowered adipose mRNA levels of resistin [1]. Additionally, there was a positive correlation between plasma resistin levels and HOMA-IR, suggesting that increased resistin secretion promotes insulin resistance [1].

Overall, the collective findings from the above adipokine studies indicate that isoflavone compounds from soy have favourable effects on insulin sensitivity, likely by up-regulating adiponectin and down-regulating resistin $[1,49,53]$. However, the evidence surrounding the effects of chickpea and soybean isoflavones on leptin levels, and the association with insulin resistance, is inconclusive at this time and requires further investigation.

\subsection{Short-Chain Fatty Acids and Gut Microflora}

Gut microflora have a substantial impact on health, with the nature of their effects determined by the specific bacteria colonizing in the gut [83]. The diet has a strong impact on the bacterial environment of the gut [83], for example, by affecting the production of short-chain fatty acids (SCFA) by intestinal fermentation $[83,84]$. SCFA (acetic, propionic, butyric acids) provide energy to colonic cells and acidify the luminal $\mathrm{pH}$, thereby suppressing the growth of pathogenic bacteria and promoting the growth of beneficial bacteria [41,83]. Evidence suggests that a high-fat diet shifts the composition of gut microflora from fewer beneficial bacteria (e.g., Bifidobacteria, Lactobacillus, Bacteroidetes) to more of the harmful bacteria (e.g., Firmicutes, Clostridium) [41,84]. This dysbiosis is a key factor in the development of insulin resistance and other metabolic diseases [41,85].

GOS are thought to act as prebiotics by enhancing the production of SCFA and thus favouring the growth of beneficial bacteria [41,84]. Zhou et al. [86] investigated the effects of commercially available soybean galactooligosaccharides (SBOS) on the gut ecosystem of Huangjiang mini-piglets (an experimental model representative of human intestinal physiology [87]). The piglets were fed a standard diet and randomly assigned to supplementation of corn starch $(0.5 \% w / w$; control group) or SBOS (0.5\% $w / w$; experimental group) for 14 days [86]. The authors reported SBOS supplementation increased total SCFA, propionate, and butyrate concentrations in the ileum and colon, as well as acetate and valerate concentrations in the ileum compared to the control group. SBOS supplementation also increased numbers of beneficial intestinal bacteria including Bifidobacterium, Faecalibacterium, Fusobacterium, and Roseburia, while decreasing numbers of potentially harmful bacteria such as Clostridium, Streptococcus, and E. coli compared to the control group [86].

A similar effect was observed in the study conducted by Dai et al. [41], where they investigated the effect of alpha-GOS ( $\alpha$-GOS) extracted from dried chickpea powder in CD-1 IGS mice fed a high-fat diet for 6 weeks. The CD-1 IGS mouse is an outbred, general, multi-purpose model that presents as a healthy phenotype [88]. As expected, consumption of a high-fat diet for 6 weeks reduced SCFA and decreased total bacterial quantity and altered gut microbiota composition [41]. Supplementation with chickpea $\alpha$-GOS $(0.083 \mathrm{~g} / \mathrm{kg} /$ day to $0.83 \mathrm{~g} / \mathrm{kg} /$ day) concurrent with HFD feeding for 6 weeks promoted the secretion of SCFA in a dose-dependent manner compared to the high-fat diet and normal chow groups. All chickpea $\alpha$-GOS treatments also significantly stimulated the growth of beneficial bacteria, Bifidobacterium and Lactobacillus, compared to the high-fat group. Although the HOMA-IR was elevated in the high-fat diet group compared to the normal control group, all the chickpea $\alpha$-GOS groups had HOMA-IR values intermediate between the high-fat diet group and the normal control group, but this was not considered statistically significant [41]. A similar study using 
male C57BL/6J mice observed that a longer duration, 18 weeks compared to 6 weeks, of high-fat feeding was required to see statistically significant effects on insulin parameters from dietary GOS supplementation $(7 \% w / w)$ [89]. Additionally, the supplemented dose of GOS was higher in the study conducted by Kavadi et al. [89], approximately 210-350 mg/day (based on an average feed intake of 3-5 g/day [90]) compared to around $21 \mathrm{mg} /$ day for the study by Dai et al. [41]. Thus, it is possible that with a longer study duration and/or higher dose of GOS the chickpea $\alpha$-GOS treatments could have reached statistical significance for HOMA-IR. Dai et al. [41] also reported no significant differences in body weight among the high-fat diet and three $\alpha$-GOS treatment groups. The lack of statistical effect on HOMA-IR by chickpea $\alpha$-GOS may be due to the weak reduction in body weight, or possibly adiposity; however, adiposity was not addressed in the study.

While a possible link between consumption of GOS from soybeans and chickpeas and improved insulin resistance was not examined in the studies by Zhou et al. [86] and Dai et al. [41], respectively, other studies have investigated the mechanism by which SCFA improve insulin resistance. Over the course of 20 weeks, supplementing a high-fat diet with 5\% w/w SCFA (acetate and propionate) in male C57BL/6J mice reduced HOMA-IR levels to that comparable with mice fed a low-fat diet, indicating improved insulin sensitivity [84]. Further investigation into the mechanism of action revealed that SCFA supplementation not only reduced total adipocyte numbers but also promoted smaller adipocytes rather than the abundance of large adipocytes observed in mice fed a supplement-free high-fat diet [84]. There was also evidence of SCFA promoting adipocyte browning, with increased cytochrome coxidase activity (an indicator of mitochondrial respiratory capacity) and expression of browning markers (e.g., Pgc1 $\alpha$ ). Lastly, it has been proposed that propionate plays a crucial role in the mechanism underlying the prevention of insulin resistance by SCFA, as evidenced by increased levels of hepatic odd-chain fatty acids (a biomarker for propionate formation) and a negative correlation between the formation of those odd-chain fatty acids in the liver and the secretion of insulin during oral glucose tolerance testing [84].

In contrast, studies have also demonstrated that GOS from sources other than soybeans and chickpeas have no effect on improving insulin sensitivity. In a study conducted by Stahel et al. [91], Sprague Dawley rats were fed a diet supplemented with GOS $(15 \% w / w)$ for nine weeks. GOS improved the microbial gut profile by increasing the abundance of Bifidobacterium spp. Lactobacillus spp., and Bacteroidetes, but it had no effect on insulin sensitivity, compared to the control group (supplemented with 15\% w/w methylcellulose) [91]. As seen with the study by Dai et al. [41], the study length may not be optimal for seeing a change in insulin sensitivity in a population without insulin resistance. However, a similar finding was observed in overweight or obese prediabetic men who received GOS supplements (15 g/day) with their regular meals for 12 weeks [92]. Supplementing with GOS increased fecal Bifidobacterium spp., but there were no changes in insulin sensitivity [92]. It is possible that GOS from legumes, rather than from milk sources, may be more beneficial for improving insulin sensitivity; variability in the properties (structural, functional) of GOS from different sources may play a role in their efficacy. Further research is required to confirm the effect of SBOS and chickpea $\alpha$-GOS on insulin sensitivity, as well as the required conditions for SBOS and chickpea $\alpha$-GOS to have an optimal effect.

\section{General Summary and Conclusions}

Soybeans and pulses have proven to be effective at improving insulin sensitivity, clinically evidenced by reductions in HOMA-IR (Table 1) $[5,17-20,23,25,26]$. Preclinical studies have attributed the insulin-sensitizing properties of soybeans and pulses, particularly chickpeas, to their bioactive compounds $[1,32,38,41,49,53,60,64,86]$. This review has summarized the current literature surrounding soybeans, chickpeas, and their bioactive compounds to improve insulin sensitivity (Tables 2 and 3). The proposed insulin-sensitizing actions of these leguminous plants are summarized in Figure 2 and Table 4. 
A

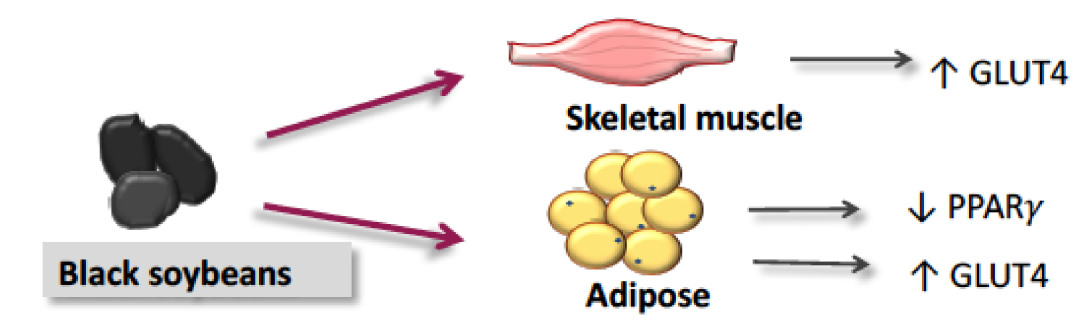

B

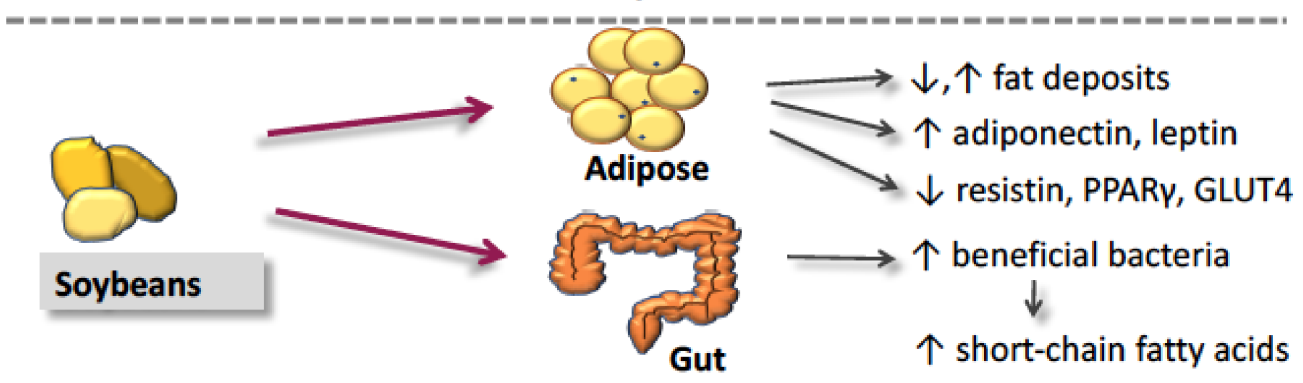

C
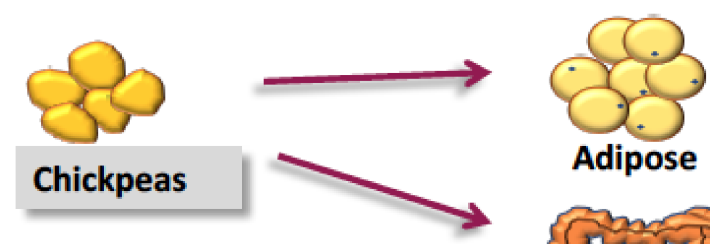

$\longrightarrow \downarrow$ fat deposits, leptin, GLUT4

Adipose
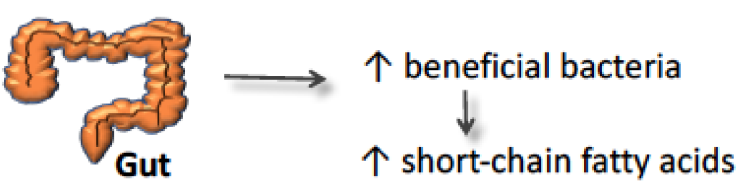

Figure 2. The proposed processes initiated by soybeans and chickpeas that lead to improved insulin sensitivity. (A) The actions of black soybeans in target tissues. (B) The actions of yellow soybeans in target tissues. (C) The actions of chickpeas in target tissues. Abbreviations: $\downarrow$, decrease; $\uparrow$, increase; GLUT4, glucose transporter-4; PPAR $\gamma$, peroxisome proliferator-activated receptor- $\gamma$.

In general, soybeans and chickpeas demonstrated efficacy on pathways related to improved insulin sensitivity when a disease condition was present $[1,38,41,49,64,66]$. In models presenting a disease condition, soybeans, chickpeas, and/or their bioactive compounds, could reduce adiposity $[1,32,62,64]$, positively affect adipokines [1,49], inhibit adipogenesis (via down-regulation of PPAR- $\gamma$ ) [32,60], increase GLUT4 levels $[38,49,53]$, and increase SCFA-producing beneficial bacteria in the gut [41]. In models where a disease condition was not present there were contrary effects from soybean and chickpea supplementation such as increased adiposity [70] and decreased leptin levels [66]. In vitro studies that did not specify the application of an induced disease state were considered to be absent of a disease condition $[32,53,60]$. From the observed findings, it is possible that in the absence of an underlying disease condition, consuming soy, chickpeas, and/or their bioactive compounds does not impose a functional benefit on insulin sensitivity, aside from providing the general nutritive value of the legumes. 
Table 2. Summary of the in vivo studies included in the present review.

\begin{tabular}{|c|c|c|c|c|}
\hline Legume Source & Reference & Study Design & Parameters Measured & Key Findings \\
\hline \multirow{3}{*}{ Soybean (Glycine max. L.) } & Zhang et al. [1] & $\begin{array}{l}\text { Male Sprague Dawley rats (150-180 g) } \\
\text { Groups: (1) Basal control (normal diet); } \\
\text { (2) HFD insulin-resistant (IR control; } \\
\text { sterilized water as vehicle control); } \\
\text { (3) HFD + low-dose ISO (50 mg/kg/day } \\
\text { intragastric administration (i.g.)); } \\
\text { (4) HFD + medium-dose ISO } \\
\text { (150 mg/kg/day i.g.); }(5) \mathrm{HFD} \mathrm{+} \\
\text { high-dose ISO (450 mg/kg/day i.g.) } \\
\text { 30-day study }\end{array}$ & $\begin{array}{l}\text { Insulin resistance index (HOMA-IR) } \\
\text { Fasting insulin (RIA kit) } \\
\text { Fasting plasma glucose (commercial } \\
\text { reagent paper) } \\
\text { Fasting plasma adiponectin, leptin, } \\
\text { resistin (rat ELISA kits) } \\
\text { Tissue weights (epididymal and } \\
\text { peri-renal fat pads) } \\
\text { mRNA levels in peri-renal adipose tissue } \\
\text { (quantitative real-time PCR (RT-PCR); } \\
45 \text { cycles) }\end{array}$ & $\begin{array}{l}\text { ISO } \downarrow \text { fat pad weights, no differences in body } \\
\text { weights among groups } \\
\text { ISO } \downarrow \text { fasting insulin and HOMA-IR vs. } \\
\text { IR control } \\
\text { ISO }(150 \text { and } 450 \mathrm{mg} / \mathrm{kg} / \text { day) } \uparrow \text { plasma and } \\
\text { mRNA adiponectin and leptin levels, } \downarrow \\
\text { plasma resistin levels } \\
\text { ISO }(450 \mathrm{mg} / \mathrm{kg} / \text { day }) \downarrow \mathrm{mRNA} \\
\text { resistin levels } \\
\text { Positive correlation between plasma resistin } \\
\text { and HOMA-IR } \\
\text { Negative correlation between plasma } \\
\text { adiponectin and HOMA-IR }\end{array}$ \\
\hline & Nizamutdinova et al. [38] & $\begin{array}{l}\text { Male Sprague Dawley rats }(220-250 \mathrm{~g}) \\
\text { Streptozotocin (STZ; } 50 \mathrm{mg} / \mathrm{kg} \text { ) injected } \\
\text { intraperitoneally to induce diabetes } \\
\text { Anthocyanins extracted from } \\
\text { black soybeans } \\
\text { Groups: (1) Control (no STZ); } \\
\text { (2) Diabetes control (STZ); (3) } \\
\text { Anthocyanin }(50 \mathrm{mg} / \mathrm{kg}) \text { pre-diabetes } \\
\text { (ANT-PRE) } \mathrm{STZ} \text { (4) STZ + } \\
\text { Anthocyanin }(50 \mathrm{mg} / \mathrm{kg} \text { ) post-diabetes } \\
\text { (ANT-POST) } \\
\text { 30-day study }\end{array}$ & $\begin{array}{ll}\text { Protein levels (Western blotting) } \\
\text { Fasting serum insulin (ELISA kit) } \\
\text { Fasting blood glucose (glucometer) }\end{array}$ & $\begin{array}{l}\text { Anthocyanins } \downarrow \text { blood glucose levels of } \\
\text { diabetic rats vs. diabetic control group } \\
\text { Anthocyanins } \uparrow \text { fasting serum insulin of } \\
\text { diabetic rats vs. diabetic control group } \\
\text { Anthocyanins } \uparrow \text { GLUT4 levels in skeletal } \\
\text { muscle vs. diabetic control group }\end{array}$ \\
\hline & Ali et al. [64] & $\begin{array}{l}\text { Male lean and obese Spontaneously } \\
\text { hypertensive rat/N-corpulent } \\
\text { (SHR/N-cp) rats (7-8 weeks old) } \\
\text { Basal diet: American Institute of } \\
\text { Nutrition 93G formula } \\
\text { Soy isoflavone (ISO) supplementation } \\
(0.1 \% w / w) \\
\text { 20-week study }\end{array}$ & $\begin{array}{l}\text { Tissue weights (peri-renal, ileal, } \\
\text { subdiaphragmatic, epididymal fat pads) }\end{array}$ & $\begin{array}{l}\text { Soy ISO } \downarrow \text { body weight of obese rats } \\
\text { Soy ISO } \downarrow \text { peri-renal, epididymal, and } \\
\text { subdiaphragmatic fat pad weights in lean } \\
\text { and obese rats } \\
\text { Soy ISO } \downarrow \text { ileal fat pads in obese rats }\end{array}$ \\
\hline
\end{tabular}


Table 2. Cont.

\begin{tabular}{|c|c|c|c|c|}
\hline Legume Source & Reference & Study Design & Parameters Measured & Key Findings \\
\hline \multirow{3}{*}{ Soybean (Glycine max. L.) } & Zanella et al. [70] & $\begin{array}{l}\text { Male C57BL6/J mice (3-weeks old) } \\
\text { Basal diet: low-fat diet (LFD) } \\
\text { Study 1 groups: (1) LFD (soy-free); } \\
\text { (2) LFD + Soybean supplementation } \\
\text { (8.5\% } w / w) \\
\text { Study } 2 \text { groups: (1) LFD + vehicle (sham } \\
\text { control); (2) LFD + genistein } \\
\text { (5 mg/kg/day by oral gavage) } \\
\text { Study 1: } 147 \text { days; Study 2: } 15 \text { days }\end{array}$ & $\begin{array}{l}\text { Glucose tolerance test (glucometer) } \\
\text { Insulin resistance test (0.75 Units insulin } \\
\text { injected intraperitoneally; tail vein } \\
\text { blood samples) } \\
\text { Body composition (Echo magnetic } \\
\text { resonance imaging) } \\
\text { Tissue weights (epididymal and } \\
\text { peri-renal fat pads) }\end{array}$ & $\begin{array}{l}\text { Soy treatment } \uparrow \text { total fat mass and } \uparrow \text { fat pad } \\
\text { mass vs. soy-free control group } \\
\text { Genistein } \uparrow \text { adipose tissue mass vs. } \\
\text { sham control } \\
\text { No differences in lean mass or total body } \\
\text { weight between groups in Study } 1 \text { or Study } 2 \\
\text { No difference in glucose metabolism or } \\
\text { insulin sensitivity between groups in Study } 1 \\
\text { or Study } 2\end{array}$ \\
\hline & Kavanagh et al. [80] & $\begin{array}{l}\text { Mature insulin-resistant female monkeys } \\
\text { (cynomolgus macaques and African } \\
\text { green monkeys) } \\
\text { Soy isoflavone (ISO) supplementation } \\
\text { (155 mg/day) } \\
4 \text {-month study }\end{array}$ & $\begin{array}{l}\text { Glucose tolerance test (femoral } \\
\text { intravenous collection: } 5,10,20,30, \\
60 \text { min) } \\
\text { Insulin resistance test } \\
\text { (hyperinsulinemic-euglycemic clamp) } \\
\text { Fasting plasma glucose } \\
\text { (colorimetric assay) } \\
\text { Fasting insulin (ELISA kit) } \\
\text { Fasting plasma adiponectin (ELISA kit) }\end{array}$ & $\begin{array}{l}\text { ISO } \uparrow \text { insulin area under the curve vs. control } \\
\text { No effect of ISO on glucose area under } \\
\text { the curve } \\
\text { No effect of ISO on circulating } \\
\text { adiponectin levels }\end{array}$ \\
\hline & Zhou et al. [86] & $\begin{array}{l}\text { Huangiiang mini-piglets (weaned at } \\
21 \text { days of age) } \\
\text { Groups: (1) Basal diet }+0.5 \% w / w \text { corn } \\
\text { starch (control); (2) Basal diet }+0.5 \% w / w \\
\text { soybean galactooligosaccharides (SBOS) } \\
\text { 14-day study }\end{array}$ & $\begin{array}{l}\text { Short-chain fatty acid analysis (intestinal } \\
\text { luminal samples by gas chromatography) } \\
\text { Gut microbial composition } \\
\text { (RT-quantitative PCR) }\end{array}$ & $\begin{array}{l}\text { SBOS } \uparrow \text { intestinal short-chain fatty acids and } \\
\text { number of beneficial bacteria vs. } \\
\text { control group } \\
\text { SBOS } \downarrow \text { numbers of harmful bacteria vs. } \\
\text { control group }\end{array}$ \\
\hline Chickpea (Cicer arietinum L.) & Dai et al. [41] & $\begin{array}{l}\text { Male CD-1 (ICR) IGS mice (6-weeks old) } \\
\alpha \text {-galactooligosaccharides ( } \alpha \text {-GOS) } \\
\text { extracted from chickpeas added to } \\
\text { drinking water } \\
\text { Groups: (1) Normal chow; (2) HFD; } \\
\text { (3) HFD + low-dose } \alpha \text {-GOS } \\
\text { (0.083 g/kg/day); }(4) \mathrm{HFD}+ \\
\text { medium-dose } \alpha \text {-GOS }(0.42 \mathrm{~g} / \mathrm{kg} / \text { day); } \\
\text { (5) } \mathrm{HFD}+\text { high-dose } \alpha \text {-GOS } \\
\text { (0.83 g/kg/day) } \\
\text { 6-week study }\end{array}$ & $\begin{array}{l}\text { Blood glucose (glucometer) } \\
\text { Serum insulin (rat/mouse insulin } \\
\text { enzyme-linked immunosorbent assay } \\
\text { (ELISA) kit) } \\
\text { Insulin resistance index (HOMA-IR) } \\
\text { Short-chain fatty acid analysis (luminal } \\
\text { samples by high-performance } \\
\text { liquid chromatography) } \\
\text { Gut microbial composition (quantitative } \\
\text { PCR of fresh fecal samples) }\end{array}$ & $\begin{array}{l}\text { HFD } \downarrow \text { short-chain fatty acids, total bacterial } \\
\text { quantity, \& altered microbial composition } \\
\alpha \text {-GOS } \uparrow \text { short-chain fatty acids vs. HFD and } \\
\text { normal chow groups } \\
\alpha \text {-GOS stimulated Bifidobacterium and } \\
\text { Lactobacillus growth vs. HFD }\end{array}$ \\
\hline
\end{tabular}


Table 2. Cont.

\begin{tabular}{|c|c|c|c|c|}
\hline Legume Source & Reference & Study Design & Parameters Measured & Key Findings \\
\hline Chickpea (Cicer arietinum L.) & Yang et al. [66] & $\begin{array}{l}\text { Male Sprague Dawley rats ( } 8 \text { weeks old) } \\
\text { Diets: (1) standard chow; (2) high-fat diet } \\
\text { (HFD); (3) HFD + chickpeas (10\% raw, } \\
\text { crushed chickpea seeds) } \\
\text { 8-month study }\end{array}$ & $\begin{array}{l}\text { Insulin tolerance test (insulin at } \\
2 \text { Units } / \mathrm{kg} \text {, intraperitoneal) } \\
\text { Oral glucose tolerance test (fasting } \\
\text { glucometer readings from tail vein) } \\
\text { Fasting serum leptin (rat leptin } \\
\text { radioimmunoassay (RIA) kit) } \\
\text { Fasting serum insulin (rat insulin } \\
\text { ELISA kit) } \\
\text { Tissue weights (epididymal fat, skeletal } \\
\text { muscle, liver) } \\
\text { Triglyceride content (Folch } \\
\text { extraction method) } \\
\text { mRNA levels (Northern blot analysis of } \\
\text { total RNA) }\end{array}$ & $\begin{array}{l}\text { Chickpeas } \downarrow \text { HOMA-IR, postprandial } \\
\text { glucose, postprandial insulin levels vs. HFD } \\
\text { Chickpeas } \downarrow \text { epididymal fat pad weight } \\
\text { vs. HFD } \\
\text { Chickpeas } \downarrow \text { hepatic and muscle triglycerides } \\
\text { vs. HFD } \\
\text { Chickpeas } \downarrow \text { leptin mRNA levels vs. HFD in } \\
\text { epididymal adipose }\end{array}$ \\
\hline $\mathrm{N} / \mathrm{A}$ & Choi et al. [65] & $\begin{array}{ll}\text { Female Sprague Dawley rats } \\
\text { (5 weeks old) } \\
\text { Ovariectomy (OVX) or sham operation } \\
\text { Groups: (1) Sham + HFD; (2) OVX + } \\
\text { HFD; (3) OVX + HFD + genistein } \\
(0.1 \% w / w ; 90 \% \text { pure) } \\
\text { 4-week study }\end{array}$ & $\begin{array}{l}\text { Fasting serum glucose (enzyme assay kit) } \\
\text { Fasting serum insulin, adiponectin, } \\
\text { leptin (ELISA kits) } \\
\text { Insulin sensitivity (HOMA-IR) } \\
\text { Tissue weights (liver and adipose) } \\
\text { Adipocyte histology (hematoxylin \& } \\
\text { eosin stain) } \\
\text { Gene expression (microarray analysis) }\end{array}$ & $\begin{array}{l}\text { Genistein } \downarrow \text { HOMA-IR vs. OVX group } \\
\text { fed HFD } \\
\text { Genistein } \downarrow \text { triglyceride accumulation and } \\
\text { gonadal fat pad ewight } \\
\text { Genistein } \downarrow \text { hepatic fatty acid } \\
\text { synthase activity } \\
\text { Genistein } \downarrow \text { fat synthesis genes } \\
\text { Genistein } \uparrow \text { fat degradation genes } \\
\text { No differences in serum adiponectin or } \\
\text { leptin between groups }\end{array}$ \\
\hline $\mathrm{N} / \mathrm{A}$ & Weitkunat et al. [84] & $\begin{array}{l}\text { Male C57BL/6J mice (8 weeks old) } \\
\text { Diets: (1) LFD; (2) HFD with 10\% dietary } \\
\text { fibre (HFD control); (3) HFD with 5\% } \\
\text { SCFA and 5\% dietary fibre } \\
\text { 30-week study }\end{array}$ & $\begin{array}{ll} & \text { Oral glucose tolerance test (fasting } \\
\text { glucometer readings from tail vein) } \\
\text { Insulin sensitivity (HOMA-IR) } \\
\text { Adipocyte histology (hematoxylin \& } \\
\text { eosin stain) } \\
\text { mRNA levels (RT-PCR) } \\
\text { Enzyme activity (developed assays) }\end{array}$ & $\begin{array}{ll}\cdot & \text { SCFA } \downarrow \text { HOMA-IR vs. HFD control group } \\
\text { Negative correlation between propionate } \\
\text { and HOMA-IR } \\
\text { SCFA } \downarrow \text { total adipocyte numbers and } \\
\text { promoted small adipocytes vs. HFD } \\
\text { control group } \\
\text { SCFA } \uparrow \text { cytochrome c oxidase activity vs. } \\
\text { HFD control group } \\
\text { SCFA } \uparrow \text { mRNA levels of adipocyte } \\
\text { browning markers }\end{array}$ \\
\hline
\end{tabular}


Table 2. Cont.

\begin{tabular}{|c|c|c|c|c|}
\hline Legume Source & Reference & Study Design & Parameters Measured & Key Findings \\
\hline N/A & Stahel et al. [91] & $\begin{array}{l}\text { Male Sprague Dawley rats }(225-250 \mathrm{~g}) \\
\text { Groups: }(1) \text { Basal diet }+15 \% \\
\text { methylcellulose (Control); (2) Basal diet + } \\
15 \% w / w \text { GOS } \\
\text { 9-week study }\end{array}$ & $\begin{array}{l}\text { Insulin sensitivity } \\
\text { (hyperinsulinemic-euglycemic clamp) } \\
\text { Gut microbial populations (DNA } \\
\text { isolated from fecal samples) }\end{array}$ & $\begin{array}{l}\text { GOS } \uparrow \text { Bifidobacterium spp., Bacteroidetes, } \\
\text { Lactobacillus spp. vs. control group } \\
\text { No differences in insulin sensitivity between } \\
\text { GOS and control }\end{array}$ \\
\hline
\end{tabular}

Abbreviations: $\downarrow$, decrease; $\uparrow$, increase; ELISA, enzyme-linked immunosorbent assay; $\alpha$-GOS, $\alpha$-galactooligosaccharides; HFD, high-fat diet; HOMA-IR, homeostasis model assessment-insulin resistance; i.g., intragastric administration; IR, insulin resistant; ISO, soy isoflavones; mRNA, messenger ribonucleic acid; RIA, radioimmunoassay; RT-PCR, quantitative real-time polymerase chain reaction; SHR/N-cp, Spontaneously hypertensive rat/N-corpulent.

Table 3. Summary of the in vitro studies included in the present review.

\begin{tabular}{|c|c|c|c|c|}
\hline Legume Source & Reference & Cell Line and Treatment & Experimental Methods & Key Findings \\
\hline Chickpea (Cicer arietinum L.) & Gao et al. [32] & $\begin{array}{ll} & \text { 3T3-L1 preadipocytes } \\
\cdot & \text { Differentiated post-confluence } \\
\text { Control treatment (DMEM) } \\
\text { Isoflavones (ISO) extracted from chickpea seeds and } \\
\text { sprouts (50 and } 100 \mu \mathrm{g} / \mathrm{mL} \text { ) } \\
\quad \text { Cells treated with chickpea isoflavones for } 48 \mathrm{~h}\end{array}$ & $\begin{array}{l}\text { Isoflavone analysis (high-performance } \\
\text { liquid chromatography (HPLC)) } \\
\text { Glucose uptake (using } \\
\text { 2-deoxy-D-[ }{ }^{3} \mathrm{H} \text {-glucose and glucose) } \\
\text { mRNA levels (quantitative real-time } \\
\text { polymerase chain reaction (RT-PCR); } \\
40 \text { cycles) } \\
\text { Protein levels (Western blotting) }\end{array}$ & $\begin{array}{l}\text { Chickpea ISO } \downarrow \text { PPAR } \gamma \text { and C/EBPa } \\
\text { mRNA and protein levels vs. control } \\
\text { in differentiated adipocytes } \\
\text { Chickpea ISO } \downarrow \text { GLUT4 mRNA and } \\
\text { protein levels vs. control in } \\
\text { differentiated adipocytes }\end{array}$ \\
\hline \multirow[t]{2}{*}{ Soybean (Glycine max. L.) } & Huang et al. [49] & $\begin{array}{l}\text { 3T3-L1 preadipocytes } \\
\text { Differentiated post-confluence } \\
\text { Insulin resistance induced ( } \mathrm{mM} \text { dexamethasone, } \\
10 \% \text { fetal bovine serum, } 10 \mathrm{mg} / \mathrm{L} \text { insulin for } 2 \text { days) } \\
\text { Vehicle }(0.1 \% \text { dimethyl sulfoxide (DMSO)) } \\
\text { Black soybean koji (BSK) powder extract }(25,50,100 \text {, } \\
200 \mu \mathrm{g} / \mathrm{mL}) \\
\text { BSK treatment for } 60 \mathrm{~h} \text { for preadipocytes } \\
\text { BSK treatment for } 8 \text { days for } \\
\text { differentiating adipocytes }\end{array}$ & $\begin{array}{l}\text { Isoflavone analysis (HPLC) } \\
\text { Glucose uptake (Benedict's Test) } \\
\text { Protein levels (Western blotting) }\end{array}$ & $\begin{array}{l}\text { BSK }(200 \mu \mathrm{g} / \mathrm{mL}) \uparrow \text { glucose uptake } \\
\text { vs. vehicle in preadipocytes } \\
\text { BSK }(25-200 \mu \mathrm{g} / \mathrm{mL}) \uparrow \mathrm{GLUT} 4 \\
\text { protein levels vs. vehicle } \\
\text { in preadipocytes } \\
\text { BSK }(50 \text { to } 200 \mu \mathrm{g} / \mathrm{mL}) \uparrow \text { adiponectir } \\
\text { protein levels vs. vehicle in } \\
\text { mature adipocytes } \\
\text { BSK }(200 \mu \mathrm{g} / \mathrm{mL}) \downarrow \text { PPAR } \gamma \text { protein } \\
\text { levels vs. vehicle in preadipocytes }\end{array}$ \\
\hline & Inaguma et al. [53] & $\begin{array}{l}\text { 3T3-L1 adipocytes } \\
\text { Differentiated after } 48 \mathrm{~h} \text {; post-confluence } \\
\text { Cyanidin-3-glucoside from black soybeans (20 and } \\
100 \mu \mathrm{M}) \text { added every } 2 \text { days for } 4 \text { days }\end{array}$ & $\begin{array}{l}\text { Gene expression levels (RT-PCR; } \\
40 \text { cycles) }\end{array}$ & $\begin{array}{l}\text { Cyanidin-3-glucoside } \uparrow \text { GLUT4 } \\
\text { mRNA levels vs. vehicle }\end{array}$ \\
\hline
\end{tabular}


Table 3. Cont.

\begin{tabular}{|c|c|c|c|c|}
\hline Legume Source & Reference & Cell Line and Treatment & Experimental Methods & Key Findings \\
\hline Soybean (Glycine max. L.) & Kim et al. [60] & $\begin{array}{l}\text { 3T3-L1 adipocytes } \\
\text { Differentiated post-confluence } \\
\text { Vehicle treatment (DMSO) } \\
\text { Black soybean anthocyanin extract (12.5 and } \\
50 \mu \mathrm{g} / \mathrm{mL} \text { ) for } 24 \text { and } 48 \mathrm{~h}\end{array}$ & $\begin{array}{ll}\text { Anthocyanin extract analysis (HPLC) } \\
\text { Protein levels (Western blotting) }\end{array}$ & $\begin{array}{l}\text { Anthocyanins }(50 \mu \mathrm{g} / \mathrm{mL}) \downarrow \operatorname{PPAR} \gamma \\
\text { protein levels vs. vehicle }\end{array}$ \\
\hline N/A & Luna-Vital et al. [54] & $\begin{array}{l}\text { 3T3-L1 adipocytes } \\
\text { Differentiated after } 48 \mathrm{~h} \\
\text { Insulin resistance induced (mTNF } \alpha 10 \mathrm{ng} / \mathrm{mL} \text { for } \\
6 \text { days) } \\
\text { Anthocyanin-rich purple corn water extract (PCW; } \\
0.4 \mathrm{mg} \text { dry sample/mL; exposure time unknown) }\end{array}$ & $\begin{array}{l}\text { Insulin sensitivity measured via glucose } \\
\text { uptake (2-NBDG assay) }\end{array}$ & $\begin{array}{l}\text { PCW } \uparrow \text { glucose uptake vs. vehicle in } \\
\text { insulin resistant adipocytes }\end{array}$ \\
\hline
\end{tabular}

Abbreviations: $\downarrow$, decrease; $\uparrow$, increase; BSK, black soybean koji extract; C/EBP $\alpha$, CCAAT-enhancer binding protein-alpha; DMSO, dimethyl sulfoxide; GLUT4, glucose transporter-4; HPLC, high-performance liquid chromatography; ISO, isoflavones; mRNA, messenger RNA; RT-PCR, quantitative real-time polymerase chain reaction; PPAR $\gamma$, peroxisome

proliferator-activated receptor-gamma.

Table 4. Summary of the proposed mechanisms of action of soybeans and chickpeas to improve insulin sensitivity.

\begin{tabular}{|c|c|c|c|c|c|c|c|c|c|}
\hline \multirow[b]{2}{*}{ Legume } & \multirow[b]{2}{*}{ Compound } & \multirow[b]{2}{*}{ Model } & \multicolumn{7}{|c|}{ Proposed Mechanisms } \\
\hline & & & GLUT4 & PPAR- $\gamma$ & Adiposity & Adiponectin & Leptin & Resistin & $\begin{array}{c}\text { Gut Microbiota } \\
\text { (SCFA-Producing Bacteria) }\end{array}$ \\
\hline \multirow[b]{2}{*}{ Black soybean } & Isoflavones & 3T3-L1 cells & $\uparrow[49]$ & $\downarrow[49]$ & $\uparrow[49]$ & $\uparrow[49]$ & & & \\
\hline & Anthocyanins & $\begin{array}{l}\text { 3T3-L1 cells } \\
\text { Diabetic rats }\end{array}$ & $\begin{array}{l}\uparrow[53] \\
\uparrow[38]\end{array}$ & $\downarrow[60]$ & & & & & \\
\hline \multirow[t]{2}{*}{ Soybean } & Isoflavones & $\begin{array}{c}\text { Insulin resistant rats } \\
\text { Lean \& obese rats } \\
\text { C57BL/6 mice } \\
\text { Insulin resistant, menopausal } \\
\text { monkeys }\end{array}$ & & & $\begin{array}{l}\downarrow[1] \\
\downarrow[64] \\
\uparrow[70]\end{array}$ & X [80] & $\uparrow[1]$ & $\downarrow[1]$ & \\
\hline & Galactooligosaccharides & Mini-piglets & & & & & & & $\uparrow[86]$ \\
\hline Chickpea & $\begin{array}{c}\text { Isoflavones } \\
\mathrm{n} / \mathrm{a} \\
\alpha \text {-galactooligosaccharides }\end{array}$ & $\begin{array}{l}\text { 3T3-L1 cells } \\
\text { SD rats } \\
\text { CD-1 mice }\end{array}$ & $\downarrow[32]$ & $\downarrow[32]$ & $\begin{array}{l}\downarrow[32] \\
\downarrow[66]\end{array}$ & & $\downarrow[66]$ & & $\uparrow[41]$ \\
\hline
\end{tabular}

Abbreviations: $\uparrow$, increased effect; $\downarrow$, decreased effect; $X$, no effect; SCFA, short-chain fatty acid; SD, Sprague Dawley. 
Nowadays, many studies infer the actions of soybeans and pulses are due to the high antioxidant activity of their bioactive compounds, such as the anthocyanins and isoflavones $[13,93,94]$. While these compounds may attenuate the oxidative stress that is associated with insulin resistance [95], the bioactive compounds of soybeans and pulses have biological effects beyond antioxidant activity and the contribution of these mechanisms inwards improving insulin sensitivity should be acknowledged. As previously discussed, isoflavones from soybeans and chickpeas reduced adiposity under disease conditions $[1,32,64,66]$, an action beneficial for improving insulin resistance. Isoflavones are suggested to inhibit lipid accumulation in adipocytes through inhibiting PPAR $\gamma$ (a marker of early- and mid-stage differentiation) [49,62], glycerol-3-phosphate dehydrogenase (a marker of late-stage differentiation) [88], and inducing apoptosis of mature adipocytes [96]. It has been demonstrated that isoflavones regulate PPAR $\gamma$ by inhibiting tyrosine phosphorylation of $C / E B P \beta$, and activating Wnt signaling and adenosine monophosphate-activated protein kinase (AMPK) pathways [97,98]. These actions produce anti-adipogenic effects that improve insulin resistance. The activation of AMPK may also be a key mechanism of action for anthocyanins. Studies have shown AMPK is activated by anthocyanins [99,100], which then increases GLUT4 translocation leading to increased glucose uptake and improved insulin sensitivity $[99,101]$. It is also suggested that anthocyanins may indirectly activate AMPK by increasing adiponectin secretion [100].

While the summarized in vitro and in vivo evidence (Tables 2 and 3) supports the potential insulin-sensitizing effects of both chickpeas $[32,41,66]$ and soybeans $[1,38,49,53,60,64]$, soybeans appear to have a more robust effect on insulin sensitivity. These findings may be due to the larger number of research studies available for soybeans compared to chickpeas; however, they may also be due to the presence of additional bioactive compounds, such as anthocyanins $[38,53,60]$, within certain varieties of soybeans (e.g., black soybeans) that are otherwise not present in chickpeas.

The question of the human relevance of the bioactive compounds used in the in vivo studies is important to consider with respect to implementing these results within the context of human consumption. Various studies have reported the mean dietary intake of isoflavones, mostly from soy sources, to be less than $5 \mathrm{mg} /$ day in the United States and across European populations [102-105]. In Asian populations, the mean isoflavone intake from dietary sources ranges from $22-47 \mathrm{mg} /$ day $[104,105]$, and among vegetarian-based diets the mean dietary intake is around $22 \mathrm{mg} /$ day [105]. Interestingly, isoflavone intakes average around $50 \mathrm{mg} /$ day among supplement users in Western countries, with certain supplements containing up to $107 \mathrm{mg}$ of isoflavones [105]. In the various studies that examined isoflavones in vivo, the highest supplement dose that produced an effect was $450 \mathrm{mg} / \mathrm{kg}$ body weight of soy isoflavones in Sprague Dawley rats (150-180 g body weight) [1]. This dose is equivalent to approximately $68-81 \mathrm{mg}$ of isoflavones/day, similar to the isoflavone supplements provided to participants in the clinical studies listed in Table $1[5,18,20]$. As for anthocyanins, average dietary intakes have been reported around $12 \mathrm{mg} /$ day in the United States [106] and $30 \mathrm{mg} /$ day in European countries [107]. There are no recommendations in place for Canada, the United States, or the European Union regarding anthocyanin intake; however, in China, the dietary recommendation is $50 \mathrm{mg}$ anthocyanins/day [106]. Human and animal studies have reported no toxic effects from high doses of anthocyanins $(9 \mathrm{~g} / \mathrm{kg}$ for rodents and around $2 \mathrm{~g} /$ day for humans) $[106,108]$. Foods such as blueberries, blackberries, and black soybeans contain on average (per $100 \mathrm{~g}$ ) $353 \mathrm{mg}, 529 \mathrm{mg}$, and $23 \mathrm{mg}$ of anthocyanins, respectively [109]. In the study conducted by Nizamutdinova et al. [38], animals consumed $50 \mathrm{mg} / \mathrm{kg} /$ day of anthocyanins from black soybeans, equating to approximately 11-12.5 mg anthocyanins/day. In terms of oligosaccharide dietary intakes, little information is available; however, around $3 \mathrm{~g} /$ day is suggested in the European diet for healthy gut microflora [110]. In the study by Dai et al. [41], mice consumed $0.083-0.83 \mathrm{~g} / \mathrm{kg} \alpha$-GOS from chickpeas per day, equating to approximately 2.1-21.0 mg/day. Han \& Baik [111] observed $144.9 \mathrm{mg} / \mathrm{g}$ of total oligosaccharides in dry chickpeas; therefore, one cup $(250 \mathrm{~g})$ of dry chickpeas would have approximately $36 \mathrm{~g}$ of oligosaccharides. However, it is important to note that oligosaccharide content does decrease substantially with cooking [111]. Overall, the dosages of isoflavones, anthocyanins, 
and $\alpha$-GOS from the in vivo studies discussed in this review are relevant to the intakes obtainable by humans, either by dietary sources or supplements.

It is known that cardiovascular disease is the prevalent cause of morbidity and mortality for individuals with diabetes [112]. Studies have shown that consumption of soybeans and the four listed pulses can improve vascular function [113-116]. Therefore, it is noteworthy to mention that while soybeans and chickpeas have proven beneficial for insulin sensitivity, soybeans and the four pulses (lentils, dried beans, dried peas, chickpeas) have positive vascular effects that may attenuate the cardiovascular complications associated with insulin resistance and diabetes.

In conclusion, the above studies have greatly increased our understanding of the role of soybeans and chickpeas for attenuating insulin resistance, and have provided convincing evidence that these leguminous plants have value as a nutritional approach for restoring insulin sensitivity that may provide even greater benefits when considering their ability to improve certain complications caused by insulin resistance. At the same time, similar information regarding the effect of the other pulses is lacking. Consequently, additional intervention studies are needed to evaluate the clinical relevance of soybeans and pulses as a means of improving insulin sensitivity and to better define the relative importance of the underlying mechanisms and pathways responsible for modulating the cellular response to insulin.

Acknowledgments: The authors' (C.G.T. and P.Z.) research program has been supported by funding from the Manitoba Pulse and Soybean Growers. J.L.C. holds a studentship from the Canadian Institutes of Health Research. No external funding was received for this work.

Author Contributions: J.L.C. contributed to the review design, evaluation of the literature, and writing and revision of the text. P.Z. and C.G.T. contributed to the review design, editing, and revision of the text. Figures 1 and 2 included in this review were prepared by the authors using Microsoft PowerPoint.

Conflicts of Interest: The authors have no conflict of interest to disclose.

\section{References}

1. Zhang, H.M.; Chen, S.W.; Zhang, L.S.; Feng, X.F. The effects of soy isoflavone on insulin sensitivity and adipocytokines in insulin resistant rats administered with high-fat diet. Nat. Prod. Res. 2008, 22, 1637-1649. [CrossRef] [PubMed]

2. Artunc, F.; Schleicher, E.; Weigert, C.; Fritsche, A.; Stefan, N.; Häring, H.U. The impact of insulin resistance on the kidney and vasculature. Nat. Rev. Nephrol. 2016, 12, 721-737. [CrossRef] [PubMed]

3. Park, S.E.; Park, C.Y.; Sweeney, G. Biomarkers of insulin sensitivity and insulin resistance: Past, present and future. Crit. Rev. Clin. Lab. Sci. 2014, 52, 180-190. [CrossRef]

4. National Institute of Diabetes and Digestive and Kidney Disorders. Available online: https://www.niddk. nih.gov/health-information/diabetes/overview/what-is-diabetes/prediabetes-insulin-resistance (accessed on 7 December 2017).

5. Llaneza, P.; González, C.; Fernández-Iñarrea, J.; Alonso, A.; Díaz, F.; Péréz-López, F.R. Soy isoflavones improve insulin sensitivity without changing serum leptin among postmenopausal women. Climacteric 2012, 15, 611-620. [CrossRef] [PubMed]

6. Medscape. Available online: https://emedicine.medscape.com/article/122501-medication (accessed on 29 November 2017).

7. Gandhi, G.R.; Jothi, G.; Antony, P.J.; Balakrishna, K.; Paulraj, M.G.; Ignacimuthu, S.; Stalin, A.; Al-Dhabi, N.A. Gallic acid attenuates high-fat diet fed-streptozotocin-induced insulin resistance via partial agonism of PPAR $\gamma$ in experimental type 2 diabetic rats and enhances glucose uptake through translocation and activation of GLUT4 in PI3K/p-Akt signaling pathway. Eur. J. Pharmacol. 2014, 745, 201-216. [CrossRef] [PubMed]

8. Afshin, A.; Micha, R.; Khatibzadeh, S.; Mozaffarian, D. Consumption of nuts and legumes and risk of incident ischemic heart disease, stroke, and diabetes: A systematic review and meta-analysis. Am. J. Clin. Nutr. 2014, 100, 278-288. [CrossRef] [PubMed]

9. Polak, R.; Phillips, E.M.; Campbell, A. Legumes: Health benefits and culinary approaches to increase intake. Clin. Diabetes 2015, 33, 198-205. [CrossRef] [PubMed] 
10. Rebello, C.J.; Greenway, F.L.; Finley, J.W. A review of the nutritional value of legumes and their effects on obesity and its related co-morbidities. Obes. Rev. 2014, 15, 392-407. [CrossRef] [PubMed]

11. Blair, R.M.; Henley, E.C.; Tabor, A. Soy foods have low glycemic and insulin response indices in normal weight subjects. Nutr. J. 2006, 5, 35. [CrossRef]

12. Mudryj, A.N.; Yu, N.; Aukema, H.M. Nutritional and health benefits of pulses. Appl. Physiol. Nutr. Metab. 2014, 39, 1197-1204. [CrossRef] [PubMed]

13. Thompson, S.V.; Winham, D.M.; Hutchins, A.M. Bean and rice meals reduce postprandial glycemic response in adults with type 2 diabetes: A cross-over study. Nutr. J. 2012, 11, 23. [CrossRef] [PubMed]

14. Pulse Canada. Available online: http://www.pulsecanada.com/about-pulse-canada/what-is-a-pulse/ (accessed on 29 January 2018).

15. Anderson, J.W.; Smith, B.M.; Washnock, C.S. Cardiovascular and renal benefits of dry bean and soybean intake. Am. J. Clin. Nutr. 1999, 70, 464s-474s. [CrossRef] [PubMed]

16. Brar, G.S.; Carter, T.E., Jr. Soybean: Glycine max (L.) Merrill. In Genetic Improvements of Vegetable Crops; Kalloo, G., Bergh, B.O., Eds.; Pergamon Press: Oxford, UK, 1993; Chapter 30; pp. 427-463.

17. Choi, M.S.; Ryu, R.; Seo, Y.R.; Jeong, T.S.; Shin, D.H.; Park, Y.B.; Kim, S.R.; Jung, U.J. The beneficial effects of soybean (Glycine $\max$ (L.) Merr.) leaf extracts in adults with prediabetes: A randomized placebo controlled trial. Food Funct. 2014, 5, 1621-1630. [CrossRef] [PubMed]

18. Choquette, S.; Riesco, E.; Cormier, E.; Dion, T.; Aubertin-Leheudre, M.; Dionne, I.J. Effects of soya isoflavones and exercise on body composition and clinical risk factors of cardiovascular diseases in overweight postmenopausal women: A 6-month double-blind controlled trial. Br. J. Nutr. 2011, 105, 1199-1209. [CrossRef] [PubMed]

19. Fei, B.B.; Ling, L.; Hua, C.; Ren, S.Y. Effects of soybean oligosaccharides on antioxidant enzyme activities and insulin resistance in pregnant women with gestational diabetes mellitus. Food Chem. 2014, 158, 429-432. [CrossRef] [PubMed]

20. Jamilian, M.; Asemi, Z. The effects of soy isoflavones on metabolic status of patients with polycystic ovary syndrome. J. Clin. Endocrinol. Metab. 2016, 101, 3386-3394. [CrossRef] [PubMed]

21. Nilsson, A.; Johnsson, E.; Ekström, L.; Björck, I. Effects of a brown beans evening meal on metabolic risk markers and appetite regulating hormones at a subsequent standardized breakfast: A randomized cross-over study. PLoS ONE 2013, 8, e59985. [CrossRef] [PubMed]

22. Reverri, E.J.; Randolph, J.M.; Steinberg, F.M.; Kappagoda, C.T.; Edirisinghe, I.; Burton-Freeman, B.M. Black beans, fiber, and antioxidant capacity pilot study: Examination of whole foods vs. functional components on postprandial metabolic oxidative stress, and inflammation in adults with metabolic syndrome. Nutrients 2015, 7, 6139-6154. [CrossRef] [PubMed]

23. Mariangeli, C.P.; Jones, P.J. Whole and fractionated yellow pea flours reduce fasting insulin and insulin resistance in hypercholesterolaemic and overweight human subjects. Br. J. Nutr. 2011, 105, 110-117. [CrossRef] [PubMed]

24. Johnson, S.K.; Thomas, S.J.; Hall, R.S. Palatability and glucose, insulin and satiety responses of chickpea floru and extruded chickpea flour bread eaten as part of a breakfast. Eur. J. Clin. Nutr. 2005, 59, 169-176. [CrossRef] [PubMed]

25. Nestel, P.; Cehun, M.; Chronopoulos, A. Effects of long-term consumption and single meals of chickpeas on plasma glucose, insulin, and triacylglycerol concentrations. Am. J. Clin. Nutr. 2004, 79, 390-395. [CrossRef] [PubMed]

26. Pittaway, J.K.; Robertson, I.K.; Ball, M.J. Chickpeas may influence fatty acid and fiber intake in an ad libitum diet, leading to small improvments in serum lipid profile and glycemic control. J. Am. Diet. Assoc. 2008, 108, 1009-1013. [CrossRef] [PubMed]

27. Ye, Y.B.; Chen, A.L.; Lu, W.; Zhuo, S.Y.; Liu, J.; Guan, J.H.; Deng, W.P.; Fang, S.; Li, Y.B.; Chen, Y.M. Daidzein and genistein fail to improve glycemic control and insulin sensitivity in Chinese women with impaired glucose regulation: A double-blind, randomized, placebo-controlled trial. Mol. Nutr. Food Res. 2015, 59, 240-249. [CrossRef] [PubMed]

28. Bourdon, I.; Olson, B.; Backus, R.; Richter, B.D.; Davis, P.A.; Schrieeman, B.O. Beans, as a source of dietary fibre, increase cholecystokinin and apolipoprotein B48 response to test meals in men. J. Nutr. 2001, 131, 1485-1490. [CrossRef] [PubMed] 
29. Winham, D.M.; Hutchins, A.M.; Johnston, C.S. Pinto bean consumption reduces biomarkers for heart disease risk. J. Am. Coll. Nutr. 2007, 26, 243-249. [CrossRef] [PubMed]

30. Clark, J.L.; Zahradka, P.; Taylor, C.G. Efficacy of flavonoids in the management of high blood pressure. Nutr. Rev. 2015, 73, 799-822. [CrossRef] [PubMed]

31. Ko, K.P. Isoflavones: Chemistry, analysis, functions and effects on health and cancer. Asian Pac. J. Cancer Prev. 2014, 15, 7001-7010. [CrossRef] [PubMed]

32. Gao, Y.; Yao, Y.; Zhu, Y.; Ren, G. Isoflavones in chickpeas inhibit adipocyte differentiation and prevent insulin resistance in 3T3-L1 cells. J. Agric. Food Chem. 2015, 63, 9696-9703. [CrossRef] [PubMed]

33. Yu, J.; Bi, X.; Chen, B. Isoflavones: Anti-inflammatory benefit and possible caveats. Nutrients 2016, $10,361$. [CrossRef] [PubMed]

34. Kim, U.H.; Yoon, J.H.; Li, H.; Kang, J.H.; Ji, H.S.; Park, K.H.; Shin, D.H.; Park, H.Y.; Jeong, T.S. Pterocarpan-enriched soy leaf extract ameliorates insulin sensitivity and pancreatic $\beta$-cell proliferation in type 2 diabetic mice. Molecules 2014, 19, 18493-18510. [CrossRef] [PubMed]

35. Rodríguez-Morató, J.; Farré, M.; Pérez-Mañá, C.; Papaseit, E.; Martínez-Riera, R.; de la Torre, R.; Pizarro, N. Pharmacokinetic comparision of soy isoflavone extracts in human plasma. J. Agric. Food Chem. 2015, 63, 6946-6953. [CrossRef] [PubMed]

36. Belwal, T.; Nabavi, S.F.; Nabavi, S.M.; Habtemariam, S. Dietary anthocyanins and insulin resistance: When food becomes a medicine. Nutrients 2017, 9, 1111. [CrossRef] [PubMed]

37. Hu, J.; Chen, G.; Zhang, Y.; Cui, B.; Yin, W.; Yu, X.; Zhu, Z.; Hu, Z. Anthocyanin composition and expression analysis of anthocyanin biosynthetic genes in kidney bean pod. Plant Phys. Biochem. 2015, 97, 304-312. [CrossRef] [PubMed]

38. Nizamutdinova, I.T.; Jin, Y.C.; Chung, J.I.; Shin, S.C.; Lee, S.J.; Seo, H.G.; Lee, J.H.; Chang, K.C.; Kim, H.J. The anti-diabetic effect of anthocyanins in streptozotocin-induced diabetic rats through glucose transporter 4 regulation and prevention of insulin resistance and pancreatic apoptosis. Mol. Nutr. Food Res. 2009, 53, 1419-1429. [CrossRef] [PubMed]

39. Koh, K.; Youn, J.E.; Kim, H.S. Identification of anthocyanins in black soybean (Glycine max (L.) Merr.) varieties. J. Food Sci. Technol. 2014, 51, 377-381. [CrossRef] [PubMed]

40. Lee, J.H.; Kang, N.S.; Shin, S.O.; Shin, S.H.; Lim, S.G.; Suh, D.Y.; Baek, I.Y.; Park, K.Y.; Ha, T.J. Characteristics of anthocyanins in the black soybean (Glycine max L.) by HPLC-DAD-ESI/MS analysis. Food Chem. 2009, 112, 226-231. [CrossRef]

41. Dai, Z.; Lyu, W.; Xie, M.; Yuan, Q.; Ye, H.; Hu, B.; Zhou, L.; Zeng, X. Effects of $\alpha$-galactooligosaccharides from chickpeas on high-fat-diet-induced metabolic syndrome in mice. J. Agric. Food Chem. 2017, 65, 3160-3166. [CrossRef] [PubMed]

42. Niittynen, L.; Kajander, K.; Korpeia, R. Galacto-oligosaccharides and bowel function. Scand. J. Food Nutr. 2007, 51, 62-66. [CrossRef]

43. U.S. Food and Drug Administration. Available online: https://www.fda.gov/downloads/Food/ IngredientsPackagingLabeling/GRAS/NoticeInventory/ucm381400.pdf (accessed on 8 December 2017).

44. Sangwan, V.; Tomar, S.K.; Ali, B.; Singh, R.R.B.; Singh, A.K. Hypoglycaemic effect of galactooligosaccharides in alloxan-induced diabetic rats. J. Diary Res. 2015, 82, 70-77. [CrossRef] [PubMed]

45. Fu, Z.; Gilbert, E.R.; Liu, D. Regulation of insulin synthesis and secretion and pancreatic Beta-cell dysfunction in diabetes. Curr. Diabetes Rev. 2013, 9, 25-53. [CrossRef] [PubMed]

46. Shan, W.F.; Chen, B.Q.; Zhu, S.J.; Jiang, L.; Zhou, Y.F. Effects of GLUT4 expression on insulin resistance in patients with advanced liver cirrhosis. J. Zheijang Univ. Sci. B 2011, 12, 677-682. [CrossRef] [PubMed]

47. Mueckler, M. Insulin resistance and the disruption of GLUT4 trafficking in skeletal muscle. J. Clin. Investig. 2001, 107, 1211-1213. [CrossRef] [PubMed]

48. Gannon, N.P.; Conn, C.A.; Vaughan, R.A. Dietary stimulators of GLUT4 expression and translocation in skeletal muscle: A mini-review. Mol. Nutr. Food Res. 2015, 59, 48-64. [CrossRef] [PubMed]

49. Huang, C.C.; Huang, W.C.; Hou, C.W.; Chi, Y.W.; Huang, H.Y. Effect of black soybean koji extract on glucose utilization and adipocyte differentiation in 3T3-L1 cells. Int. J. Mol. Sci. 2014, 15, 8280-8292. [CrossRef] [PubMed]

50. Sánchez-Solana, B.; Laborda, J.; Baladrón, V. Mouse resistin modulates adipogenesis and glucose uptake in 3T3-L1 preadipocytes through the ROR1 receptor. Mol. Endocrinol. 2012, 26, 110-127. [CrossRef] [PubMed] 
51. Zhou, Y.; Liu, B.L.; Liu, K.; Tang, N.; Huang, J.; An, Y.; Li, L. Establishment of the insulin-resistance induced by inflammatory response in 3T3-L1 preadipocytes cell line. Inflammation 2008, 31, 355-364. [CrossRef] [PubMed]

52. Lo, K.A.; Labadorf, A.; Kennedy, N.J.; Han, M.S.; Yap, Y.S.; Matthews, B.; Xin, X.; Sun, L.; Davis, R.J.; Lodish, H.F.; et al. Analysis of in vitro insulin resistance models and their physiological relevance to in vivo diet-induced adipose insulin resistance. Cell Rep. 2013, 5, 259-270. [CrossRef] [PubMed]

53. Inaguma, T.; Han, J.; Isoda, H. Improvement of insulin resistance by cyanidin 3-glucoside, anthocyanin from black beans through the up-regulation of GLUT4 gene expression. BMC Proc. 2011, 5, 21. [CrossRef] [PubMed]

54. Luna-Vital, D.; Weiss, M.; Gonzalez de Mejia, E. Anthocyanins from purple corn ameliorated tumor necrosis factor- $\alpha$-induced inflammation and insulin resistance in 3T3-L1 adipocytes via activation of insulin signaling and enhanced GLUT4 translocation. Mol. Nutr. Food Res. 2017, 61, 1700362. [CrossRef] [PubMed]

55. Halzuík, M.M.; Halzuík, M. PPAR- $\alpha$ and insulin sensitivity. Physiol. Rev. 2006, 55, 115-122.

56. Ferré, P. The biology of peroxisome proliferator-activated receptors: Relationship with lipid metabolism and insulin sensitivity. Diabetes 2004, 53, S43-S50. [CrossRef] [PubMed]

57. Leonardini, A.; Laviola, L.; Perrini, S.; Natalicchio, A.; Giorgino, F. Cross-talk between PPAR $\gamma$ and insulin signaling and modulation of insulin sensitivity. PPAR Res. 2009, 2009, 1-12. [CrossRef] [PubMed]

58. Olefsky, J.M.; Saltiel, A.R. PPAR $\gamma$ and the treatment of insulin resistance. Trends Endocrinol. Metab. 2000, 11, 362-368. [CrossRef]

59. Wagner, J.D.; Zhang, L.; Shadoan, M.K.; Kavanagh, K.; Chen, H.; Trenasari, K.; Kaplan, J.R.; Adams, M.R. Effects of soy protein and isoflavones on insulin resistance and adiponectin in male monkeys. Metabolism 2008, 57, 524-531. [CrossRef] [PubMed]

60. Kim, H.K.; Kim, J.N.; Han, S.N.; Nam, J.H.; Na, H.N.; Ha, T.J. Black soybean anthocyanins inhibit adipocyte differentiation in 3T3-L1 cells. Nutr. Res. 2012, 32, 770-777. [CrossRef] [PubMed]

61. Kadowaki, T.; Hara, K.; Kubota, N.; Tobe, K.; Terauchi, Y.; Yamauchi, T.; Eto, K.; Kadowaki, H.; Noda, M.; Hagura, R.; et al. The role of PPAR $\gamma$ in high-fat diet-induced obesity and insulin resistance. J. Diabetes Complicat. 2002, 16, 41-45. [CrossRef]

62. Metzger, D.; Imai, T.; Jiang, M.; Takukawa, R.; Desvergne, B.; Wahil, W.; Chambon, P. Functional role of RXRs and PPAR $\gamma$ in mature adipocytes. Prostagland. Leukot. Essent. Fat. Acids 2005, 73, 51-58. [CrossRef] [PubMed]

63. Kubota, N.; Terauchi, Y.; Miki, H.; Tamemoto, H.; Yamauchi, T.; Komeda, K.; Saton, S.; Nakano, R.; Ishii, C.; Sugiyama, T.; et al. PPAR $\gamma$ mediates high-fat diet-induced adipocyte hypertrophy and insulin resistance. Mol. Cell 1999, 4, 597-609. [CrossRef]

64. Ali, A.A.; Velasquez, M.T.; Hansen, C.T.; Mohamed, A.I.; Bhathena, S.J. Effects of soybean isoflavones, probiotics, and their interactions on lipid metabolism and endocrine system in an animal model of obesity and diabetes. J. Nutr. Biochem. 2004, 15, 583-590. [CrossRef] [PubMed]

65. Choi, J.S.; Koh, I.U.; Song, J. Genistein reduced insulin resistance index through modulating lipid metabolism in ovariectomized rats. Nutr. Res. 2012, 32, 844-855. [CrossRef] [PubMed]

66. Yang, Y.; Zhou, L.; Gu, Y.; Zhang, Y.; Tang, J.; Li, F.; Shang, W.; Jiang, B.; Yue, W.; Chen, M. Dietary chickpeas reverse visceral adiposity, dyslipidaemia and insulin resistance in rats induced by a chronic high-fat diet. Br. J. Nutr. 2007, 98, 720-726. [CrossRef] [PubMed]

67. El-Adawy, T.A. Nutritional composition and anti-nutritional factors of chickpeas (Cicer arietinum L.) undergoing different cooking methods and germination. Plant Foods Hum. Nutr. 2002, 57, 83-92. [CrossRef] [PubMed]

68. Pulse Canada. Available online: http://www.pulsecanada.com/wp-content/uploads/2017/12/CookingWith-Pulses.pdf (accessed on 29 January 2018).

69. Hernandez, C.M.; Høifødt, H.; Terry, A.V., Jr. Spontaneously hypertensive rats: Further evaluation of age-related memory performance and cholinergic marker expression. J. Psychiatry Neurosci. 2003, 28, 197-209. [PubMed]

70. Zanella, I.; Marrazzo, E.; Biasiotto, G.; Penza, M.; Romani, A.; Vignolini, P.; Caimi, L.; Di Lorenzo, D. Soy and the soy isoflavone genistein promote adipose tissue development in male mice on a low-fat diet. Eur. J. Nutr. 2015, 54, 1095-1107. [CrossRef] [PubMed] 
71. Vidal-Puigi, A.; O'Rahilly, S. Resistin: A new link between obesity and insulin resistance. Clin. Endocrinol. 2001, 55, 437-438. [CrossRef]

72. Kwon, H.; Pessin, J.E. Adipokines mediate inflammation and insulin resistance. Front. Endocrinol. (Lausanne) 2013, 4, 71. [CrossRef] [PubMed]

73. Rabe, K.; Lehrke, M.; Parhofer, K.G.; Broedl, U.C. Adipokines and insulin resistance. Mol. Med. 2008, 14, 741-751. [CrossRef] [PubMed]

74. Guilherme, A.; Virbasius, J.V.; Puri, V.; Czech, M.P. Adipocyte dysfunctions linking obesity to insulin resistance and type 2 diabetes. Nat. Rev. Mol. Cell Biol. 2008, 9, 367-377. [CrossRef] [PubMed]

75. Jung, U.J.; Choi, M.S. Obesity and its metabolic complications: The role of adipokines and the relationship between obesity, inflammation, insulin resistance, dyslipidemia, and nonalcoholic fatty liver disease. Int. J. Mol. Sci. 2014, 15, 6184-6223. [CrossRef] [PubMed]

76. Kashino, I.; Nanri, A.; Kurotani, K.; Akter, S.; Yasuda, K.; Sato, M.; Hayabuchi, H.; Mizoue, T. Association of dietary patterns with serum adipokines among Japanese: A cross-sectional study. Nutr. J. 2015, 14, 58. [CrossRef] [PubMed]

77. Clark, J.L.; Taylor, C.G.; Zahradka, P. Exploring the cardio-metabolic relevance of T-cadherin: A pleiotropic adiponectin receptor. Endocrinol. Metab. Immune Disord. Drug. Targets 2017, 17, 200-206. [CrossRef] [PubMed]

78. Balsan, G.A.; da Costa Vieira, J.L.; de Oliveira, A.M.; Portal, V.L. Relationship between adiponectin, obesity, and insulin resistance. Rev. Assoc. Med. Bras. 2015, 61, 72-80. [CrossRef] [PubMed]

79. Han, J.; Inaguma, T.; Isoda, H. Cyanidin-3-glucoside anthocyanin from black beans has potential to protect insulin resistance on 3T3-L1 adipocytes by inhibiting TNF- $\alpha$ release. Br. J. Nutr. 2018, in press.

80. Kavanagh, K.; Jones, K.L.; Zhang, L.; Flynn, D.M.; Shadoan, M.K.; Wagner, J.D. High isoflavone soy diet increases insulin secretion without decreasing insulin sensitivity in premenopausal nonhuman primates. Nutr. Res. 2008, 28, 368-376. [CrossRef] [PubMed]

81. Antuna-Puente, B.; Feve, B.; Fellahi, S.; Bastard, J.P. Adipokines: The missing link between insulin resistance and obesity. Diabetes Metab. 2008, 34, 2-11. [CrossRef] [PubMed]

82. Paz-Filho, G.; Mastronardi, C.; Wang, M.L.; Licinio, J. Leptin therapy, insulin sensitivity, and glucose homeostasis. Indian Endocrinol. Metab. 2012, 16, S549-S555. [CrossRef] [PubMed]

83. O'Connor, S.; Chouinard-Castonguay, S.; Gagnon, C.; Rudkowska, I. Prebiotics in the management of components of the metabolic syndrome. Maturitas 2017, 104, 11-18. [CrossRef] [PubMed]

84. Weitkunat, K.; Stuhlmann, C.; Postel, A.; Rumberger, S.; Fankhänel, M.; Woting, A.; Petzke, K.J.; Gohlke, S.; Schulz, T.J.; Blaut, M.; et al. Short-chain fatty acids and inulin, but not guar gum, prevent diet-induced obesity and insulin resistance through differential mechanisms in mice. Sci. Rep. 2017, 7, 6109. [CrossRef] [PubMed]

85. Murphy, E.A.; Velazquez, K.T.; Herbert, K.M. Influence of high-fat-diet on gut microbiota: A driving force for chronic disease risk. Curr. Opin. Clin. Nutr. Metab. Care 2015, 18, 515-520. [CrossRef] [PubMed]

86. Zhou, X.L.; Kong, X.F.; Lian, G.Q.; Blachier, F.; Geng, M.M.; Yin, Y.L. Dietary supplementation with soybean oligosaccharides increases short-chain fatty acids but decreases protein-derived catabolites in the intestinal luminal content of weaned Huangjiang mini-piglets. Nutr. Res. 2014, 34, 780-788. [CrossRef] [PubMed]

87. Fu, D.; Yang, H.S.; Kong, X.; Blachier, F.; Wang, W.; Yin, Y. Molecular cloning and expression profiling of excitatory amino acid carrier 1 in suckling Huangjiang mini-piglets with large or small body weight at birth. Mol. Biol. Rep. 2012, 40, 3341-3350. [CrossRef] [PubMed]

88. Charles River. Available online: https://www.criver.com/products-services/find-model/cd-1-igs-mouse? region=3611 (accessed on 5 December 2017).

89. Kavadi, P.K.; Pothuraj, R.; Chagalamarri, J.; Bhakri, G.; Mallepogu, A.; Sharma, R.K. Dietary incorporation of whey protein isolate and galactooligosaccharides exhibits improvement in glucose homeostasis and insulin resistance in high fat diet fed mice. J. Intercult. Ethnopharmacol. 2017, 6, 326-332. [CrossRef] [PubMed]

90. Research Diets. Available online: http://www.researchdiets.com/resource-center-page/typical-food-intake (accessed on 29 January 2018).

91. Stahel, P.; Kim, J.J.; Xiao, C.; Cant, J.P. Of the milk sugars, galactose, but not prebiotic galacto-oligosaccharide, improves insulin sensitivity in male Sprague Dawley rats. PLoS ONE 2017, 12, e0172260. [CrossRef] [PubMed] 
92. Canfora, E.E.; van der Beek, C.M.; Hermes, G.D.A.; Goossens, G.H.; Jocken, J.W.E.; Holst, J.J.; van Ejik, H.M.; Venema, K.; Smidt, H.; Zoetendal, E.G.; et al. Supplementation of diet with galacto-oligosaccharides increases Bifidobacteria, but not insulin sensitivity, in obese prediabetic individuals. Gastroenterology 2017, 153, 87-97. [CrossRef] [PubMed]

93. Wang, Q.; Ge, X.; Tian, X.; Zhang, Y.; Zhang, J.; Zhang, P. Soy isoflavone: The multipurpose phytochemical (review). Biomed. Res. 2013, 1, 697-701. [CrossRef] [PubMed]

94. Yoon, G.E.; Park, S. Antioxidant action of soy isoflavones on oxidative stress and antioxidant enzyme activities in exercised rats. Nutr. Res. Pract. 2014, 8, 618-624. [CrossRef] [PubMed]

95. Zhang, Z.F.; Zheng, Y.L.; Wu, D.M.; Hu, B.; Shan, Q.; Cheng, W.; Li, M.Q.; Sun, Y.Y. Purple sweet potato color attenuates hepatic insulin resistance via blocking oxidative stress in high-fat-diet-treated mice. J. Nutr. Biochem. 2013, 24, 1008-1018. [CrossRef] [PubMed]

96. Medjakovic, S.; Mueller, M.; Jungbauer, A. Potential health-modulating effects of isoflavones and metabolites via activation of PPAR and AhR. Nutrients 2010, 2, 241-279. [CrossRef] [PubMed]

97. Feng, S.; Reuss, L.; Wang, Y. Potential of natural products in the inhibition of adipogenesis through regulation of PPAR $\gamma$ expression and/or its transcriptional activity. Molecules 2016, 21, 1278. [CrossRef]

98. Hossain, M.K.; Dayem, A.A.; Han, J.; Yin, Y.; Kim, K.; Saha, S.K.; Yang, G.M.; Choi, H.Y.; Cho, S.G. Molecular mechanisms of the anti-obesity and anti-diabetic properties of flavonoids. Int. J. Mol. Sci. 2016, 17, 569. [CrossRef] [PubMed]

99. Li, D.; Wong, P.; Zuo, Y.; Zhao, M.; Chen, F. Health benefits of anthocyanins and molecular mechanisms: Update from recent decade. Crit. Rev. Food Sci. Nutr. 2017, 57, 1729-1741. [CrossRef] [PubMed]

100. Tsuda, T.; Ueno, Y.; Aoki, H.; Koda, T.; Horio, F.; Takahashi, N.; Kawada, T.; Osawa, T. Anthocyanin enhances adipocytokine secretion and adipocyte-specific gene expression in isolated rat adipocytes. Biochem. Biophys. Res. Commun. 2004, 316, 148-157. [CrossRef] [PubMed]

101. Huang, B.; Wong, Z.; Park, J.H.; Ryu, O.H.; Choi, M.K.; Lee, J.Y.; Kang, Y.H.; Lim, S.S. Anti-diabetic effect of purple corn extract on c57BL/KsJ db/db mice. Nutr. Res. Pract. 2015, 9, 22-29. [CrossRef] [PubMed]

102. Chun, O.K.; Chung, S.J.; Sang, W.O. Urinary isoflavones and their metabolites validate the dietary isoflavone intakes in US adults. J. Am. Diet. Assoc. 2009, 109, 245-254. [CrossRef] [PubMed]

103. Filiberto, A.C.; Mumford, S.L.; Pollack, A.Z.; Zhang, C.; Yeung, E.H.; Perkins, N.J.; Wactawski-Wende, J.; Schisterman, E.F. Habitual dietary isoflavone intake is associated with decreased C-reative protein concentrations among healthy premenopausal women. J. Nutr. 2013, 143, 900-906. [CrossRef] [PubMed]

104. Pop, E.A.; Fischer, L.M.; Coan, A.D.; Gitzinger, M.; Nakamura, J.; Zeisel, S.H. Effects of a high daily dose of soy isoflavones on DNA damage, apoptosis and estrogenic outcomes in healthy, postmenopausal women-A Phase I clinical trial. Menopause 2008, 15, 684-692. [CrossRef] [PubMed]

105. Van der Velpen, V.; Hollman, P.C.; van Nielen, M.; Schouten, E.G.; Mensink, M.; van't Veer, P.; Geelen, P. Large inter-individual variation in isoflavone plasma concentration limits use of isoflavone intake data for risk assessment. Eur. J. Clin. Nutr. 2014, 68, 1141-1147. [CrossRef] [PubMed]

106. Wallace, T.C. Anthocyanins. Adv. Nutr. 2015, 6, 620-622. [CrossRef] [PubMed]

107. Grosso, G.; Stepaniak, U.; Topor-Mądry, R.; Szafraniec, K.; Pająk, A. Estimated dietary intake and major food sources of polyphenols in the Polish arm of the HAPIEE study. Nutrition 2014, 30, 1398-1403. [CrossRef] [PubMed]

108. Khoo, H.E.; Azlan, A.; Tang, S.T.; Lim, S.M. Anthocyanidins and anthocyanins: Colored pigments as food, pharmaceutical ingredients, and the potential health benefits. Food Nutr. Res. 2017, 61, 1361779. [CrossRef] [PubMed]

109. Wu, X.; Beecher, G.R.; Holden, J.M.; Haytowitz, D.B.; Gebhardt, S.E.; Prior, R.L. Concentrations of anthocyanins in common foods in the United States and estimation of normal consumption. J. Agric. Food Chem. 2006, 54, 4069-4075. [CrossRef] [PubMed]

110. Laurentin, A.; Edwards, C.A. Carbohydrates: Resistance starch and oligosaccharides. In Guide to Nutritional Supplements; Caballero, E., Ed.; Elsevier Ltd.: Oxford, UK, 2009; pp. 84-92.

111. Han, I.H.; Baik, B.Y. Oligosaccharide content and composition of legumes and their reduction by soaking, cooking, ultrasound, and high hydrostatic pressure. Cereal Chem. 2006, 83, 428-433. [CrossRef]

112. Leon, B.M.; Maddox, T.M. Diabetes and cardiovascular disease: Epidemiology, biological mechanisms, treatment recommendations and future research. World J. Diabetes 2015, 6, 1246-1258. [CrossRef] [PubMed] 
113. Beavers, D.P.; Beavers, K.M.; Miller, M.; Stamey, J.; Messina, M.J. Exposure to isoflavone-containing soy products and endothelial function: A Bayesian meta-analysis of randomized controlled trials. Nutr. Metab. Cardiovasc. Dis. 2012, 22, 182-191. [CrossRef] [PubMed]

114. Hanson, M.G.; Zahradka, P.; Taylor, C.G. Lentil-based diets attenuate hypertension and large-artery remodelling in spontaneously hypertensive rats. Br. J. Nutr. 2014, 111, 690-698. [CrossRef] [PubMed]

115. Hanson, M.G.; Taylor, C.G.; Wu, Y.; Anderson, H.D.; Zahradka, P. Lentil consumption reduces resistance artery remodeling and restores arterial compliance in the spontaneously hypertensive rat. J. Nutr. Biochem. 2016, 37, 30-38. [CrossRef] [PubMed]

116. Zahradka, P.; Wright, B.; Weighell, W.; Blewett, H.; Baldwin, A.O.K.; Guzman, R.P.; Taylor, C.G. Daily non-soy legume consumption reverses vascular impairment due to peripheral artery disease. Atherosclerosis 2013, 230, 310-314. [CrossRef] [PubMed]

(C) 2018 by the authors. Licensee MDPI, Basel, Switzerland. This article is an open access article distributed under the terms and conditions of the Creative Commons Attribution (CC BY) license (http://creativecommons.org/licenses/by/4.0/). 